\title{
Do Firms Choose Their Stock Liquidity? A Study of Innovative Firms and Their Stock Liquidity*
}

\author{
Nishant Dass, Vikram Nanda, Steven Chong Xiao ${ }^{\dagger}$
}

August 9, 2012

\begin{abstract}
We ask whether firms can choose, or at least influence, their stock liquidity. We analyze a sample of firms that, we hypothesize, will value stock liquidity more than other firms - innovative firms that primarily hold intangible assets and expect to raise capital from the stock market. Consistent with their reliance on equity markets, we find that innovative firms have higher liquidity and that they take a variety of actions (e.g., frequent earnings guidance, stock splits etc) that help keep their stock more liquid. Maintaining liquidity appears to be less of a concern when innovative firms have greater access to other sources of capital. Given their low leverage, there is greater reliance on monitoring by large equity-holders and incentive contracts to help resolve agency issues, rather than banks or other creditors: consistent with the greater institutional ownership, higher likelihood of blockholders, and more incentivized CEO compensation contracts in these firms. The marginal impact on firm value (Tobin's $Q$ ) of a plausibly exogenous increase in liquidity (e.g., following decimalization of stock prices) is greater for innovative firms, especially when CEOs have strong incentive contracts. Innovative activity tends to increase in the wake of such liquidity enhancements.
\end{abstract}

Keywords: Stock Liquidity, Innovative Firms

JEL Codes: G14, G30

\footnotetext{
${ }^{*}$ We would like to thank Alex Edmans, Nikunj Kapadia, Simi Kedia, Pete Kyle, Alexander Ljungqvist, Albert Menkveld; seminar participants at the Georgia Institute of Technology, Rutgers University; and conference participants at the Liquidity Risk Management 2012 Conference at Fordham University, Tinbergen Institute - Society for Financial Econometrics (TI-SoFiE) 2012 Conference in Amsterdam for their helpful comments and discussions. We also thank Alex Edmans for sharing the data on wealth-performance sensitivity, that are constructed in Edmans, Gabaix, and Landier (2009).

${ }^{\dagger}$ College of Management, Georgia Institute of Technology, 800 West Peachtree St. NW, Atlanta, GA 30308.
} 


\title{
Do Firms Choose Their Stock Liquidity? A Study of Innovative Firms and Their Stock Liquidity
}

\begin{abstract}
We ask whether firms can choose, or at least influence, their stock liquidity. We analyze a sample of firms that, we hypothesize, will value stock liquidity more than other firms - innovative firms that primarily hold intangible assets and expect to raise capital from the stock market. Consistent with their reliance on equity markets, we find that innovative firms have higher liquidity and that they take a variety of actions (e.g., frequent earnings guidance, stock splits etc) that help keep their stock more liquid. Maintaining liquidity appears to be less of a concern when innovative firms have greater access to other sources of capital. Given their low leverage, there is greater reliance on monitoring by large equity-holders and incentive contracts to help resolve agency issues, rather than banks or other creditors: consistent with the greater institutional ownership, higher likelihood of blockholders, and more incentivized CEO compensation contracts in these firms. The marginal impact on firm value (Tobin's $Q$ ) of a plausibly exogenous increase in liquidity (e.g., following decimalization of stock prices) is greater for innovative firms, especially when CEOs have strong incentive contracts. Innovative activity tends to increase in the wake of such liquidity enhancements.
\end{abstract}

Keywords: Stock Liquidity, Innovative Firms

JEL Classification: 614, G30 


\section{Introduction}

There is a substantial literature in market microstructure that is devoted to the study of stock liquidity or the lack thereof: illiquidity (see Easley and O'Hara 2003, for a survey). In general, stock illiquidity is believed to reflect two types of costs - those due to adverse selection arising from the information asymmetry between market participants and a non-information component that is attributed to inventory/transactions costs. While the influence of liquidity on asset prices is far from resolved, the liquidity of an asset is usually regarded as a desirable feature. The question this raises is whether firms seek to control or at least influence their stock liquidity. ${ }^{1}$ Firms can, for instance, take actions to increase their transparency and lower information asymmetry in the market, as well as adopt policies such as stock-splits and stock offerings, that could enhance trading volume and, thereby, encourage price discovery. In this paper, our objective is to investigate whether and how firms attempt to enhance their stock liquidity, and what the implications are for firm value. This is done in the context of firms that, we hypothesize, are more reliant on the stock market for external financing and, hence, would be expected to value stock liquidity more than other firms.

We draw upon the existing literature on capital structure choice to identify a set of firms that are shown to have lower leverage - specifically, the firms that produce unique or specialized products. Titman and Wessels (1988) have argued that firms whose products are unique - proxied by firms that are more innovative and have brand value - will have greater ripple effects of bankruptcy on their customers, suppliers, and workers. As a result, these firms will have lower leverage ratios in equilibrium. Further, assets that are essential in generating unique products, such as intellectual property, are often intangible and/or have lower collateral value, and will thus result in lower firm leverage. ${ }^{2}$ Equity financing may also be better matched to the needs of firms developing innovative products and technologies that have a longer gestation period and may require greater managerial discretion.

\footnotetext{
${ }^{1}$ The notion that firms can affect and benefit from an increase in their liquidity is discussed, for instance, in Amihud and Mendelson (1991). They argue that "companies ... can benefit by undertaking steps to increase the liquidity of their claims".

${ }^{2}$ In our sample, firms that invest in R\&D have a mean (median) leverage ratio of $16.9 \%$ (10.7\%); this is significantly smaller in comparison with the corresponding figures for non-R\&D firms that have a $27.9 \%$ mean and $25.7 \%$ median leverage ratio. These and other univariate tests are reported in Panels A-E of Table 2.
} 
We argue that, as a result of their greater reliance on external equity financing, innovative firms will place a greater value on stock liquidity. We, therefore, expect these firms to take various steps to keep/make the firm more transparent and, thereby, their stock more liquid. Liquidity enhancements for such firms are also likely to have greater value consequences than for other firms. As a corollary, if these firms do raise debt, it is more likely to be highly-rated public debt; and, if they use bank financing, then it is likely to come with relatively fewer covenants. We classify firms as innovative either by their investments in $R \& D$ or by the number of their patents/citations. ${ }^{3}$

We test these arguments in a sample of firms from the merged CRSP and Compustat data over 1990-2006. Using a variety of liquidity measures, we first investigate whether these types of firms indeed have greater liquidity. We find strong empirical support for this prediction. Specifically, we find that innovative firms tend to have lower stock illiquidity (measured a là Amihud, 2002), higher stock turnover, lower bid-ask spread, and a lower probability of informed trading (as measured by the PIN proposed in Easley et al., 2002). We also confirm our results by combining the various attributes of innovation into an index using principal components (henceforth, the "innovation index"). The results are not only statistically significant, but they are also economically meaningful - e.g., a 10 percentage point increase in $\mathrm{R} \& \mathrm{D}$ is associated with $7.4 \%$ lower illiquidity, $10.8 \%$ higher turnover, $10.5 \%$ lower bid-ask spread, and $4.2 \%$ lower PIN from the mean. ${ }^{4}$ This is an important finding because we might expect innovative firms, whose investments are likely to be informationally more opaque for the market, to have a lower stock liquidity (Gopalan et al., 2011). However, what we find is that these firms have higher stock liquidity. This finding suggests that the firms that are most at risk of being adversely affected by illiquidity choose policies intended to overcome these problems.

We argue that when an innovative firm is less financially constrained and has access to other sources of capital, it is less reliant on equity markets and, therefore, it may not need to manage its stock liquidity as aggressively. Consistent with this, we find that the relationship between measures

\footnotetext{
${ }^{3}$ As a robustness check, we also examine firms on the basis of their advertising expenditures instead of innovation activity to identify firms that produce unique products.

${ }^{4}$ Amihud's measure, bid-ask spread, and PIN, all reflect illiquidity; turnover, however, proxies for liquidity. Therefore, we use the negative of turnover in our tests to make it consistent with the other three measures.
} 
of innovation and stock liquidity is weaker when the firm is less financially constrained. Specifically, we find that the negative relation between the innovation index and the above four measures of illiquidity is significantly weaker when the firm is less cash constrained, using indicators such as outstanding public debt, higher credit ratings, dividend payout or the ability to extract more trade credit. Overall, this supports the underlying premise that firms manage their stock liquidity when they are particularly reliant on equity markets for their capital needs.

In order to improve their stock liquidity, innovative firms can take steps to lower the information asymmetry between insiders and the rest of the market. We take our cue from the existing finance and accounting literatures that have shown the effects of firms' actions on information asymmetry around their stock. We show that innovative firms are much more likely to take deliberate actions that are known to lower information asymmetry and correspondingly enhance their stock liquidity. For instance, Coller and Yohn (1997) have shown that management is likely to provide earnings guidance when there is greater information asymmetry about the firm, and that this information asymmetry is reduced after the management's guidance. We find that innovative firms are more likely to provide management guidance - e.g., a one standard deviation increase in innovation index is associated with a 3\% increase in the frequency of earnings guidance from the firm's management. Literature on stock splits (e.g., Muscarella and Vetsuypens, 1996; Lin et al., 2009) has found support for the hypothesis that these events lead to an increase in stock liquidity. Correspondingly, we find that, conditional on stock prices, innovative firms are more likely to split their stock.

A variety of other corporate policies can also help innovative firms maintain their stock liquidity. Specifically, these firms are more likely to make seasoned equity offerings and they are also more likely to rely on the services of 'more reputed' underwriters (defined later) for security issuance. SEOs can help increase the investor base and, therefore, improve the stock liquidity (Merton, 1987; Eckbo et al., 2000; and Butler et al., 2005); while more reputed underwriters can play a key role in increasing liquidity by, for instance, helping access a wider investor base, providing price support and playing the role of a market maker (Amihud and Mendelson, 1988; Ellis, Michaely and O'Hara, 2000). Finally, we find that actions taken by innovative firms to enhance liquidity - and 
the associated greater stock trading - may also make it more likely that options on their stock are listed on exchanges (Mayhew and Mihov, 2004).

We explicitly test whether these actions improve the firm's liquidity. Given that firms take these actions endogenously, we establish the causal effect of these actions in improving liquidity by using an instrumental variable regression. We instrument for the firms' actions, such as managerial guidance and the decisions to split the stock or issue seasoned equity offerings, with their respective industry median or mean (excluding the firm itself). ${ }^{5}$ Using this methodology, we find evidence that these actions do reduce the stock's illiquidity.

When innovative firms raise debt financing, there are certain types/features of debt that we would expect them to prefer. We find that innovative firms are more likely to issue debt if it is public and receives higher credit ratings, and less likely to have any accounting-based quantitative financial covenants (or fewer quantitative covenants, conditional on having them) in their loans. These results suggest some aspects about the behavior of innovative firms: first, they go to capital markets, which can help lower the information asymmetry in the market (Easterbrook, 1984); second, they maintain higher credit ratings, which eases raising capital, especially because their assets are typically intangible and cannot be collateralized easily (Odders-White and Ready, 2006); and finally, given the long-term nature of their investments, they prefer to raise capital such that there are fewer "interruptions" and more managerial discretion.

But given the fewer quantitative financial covenants in their bank loans and the generic nature of covenants in public debt (Chava, Kumar, and Warga, 2010), the monitoring of managers will be more dependent on large shareholders . To that effect, we find that innovative firms are more likely to have a larger institutional ownership of their equity and to also have more blockholders. Edmans and Manso (2011) have shown that these equity holders are better at monitoring. These firms also rely more heavily on equity-based incentives in their CEO compensation contracts. This finding is consistent with Holmstrom and Tirole (1993), who argue that stronger equity incentives can, in equilibrium, induce managers to enhance stock liquidity - which, in turn, makes the equity-based

\footnotetext{
${ }^{5}$ We use means when the variable of interest is a dummy variable and the median is zero.
} 
incentive contracts more effective.

Fang, Noe, and Tice (2009) show that stock liquidity is positively associated with firm value. Using an exogenous change in stock illiquidity, we show that this positive relation between stock liquidity and the firm's Tobin's Q is particularly strong for innovative firms as they value liquidity more than other firms. To establish the causal effect of the change in (il)liquidity on the change in Tobin's Q, we either instrument the change in illiquidity with its industry median or analyze the change in liquidity due to a plausibly exogenous event. We consider two such events - the decimalization of stock prices in April 2001 and addition of the firm to the S\&P 500 Index. We show that the impact of these exogenous changes in liquidity on firm value is significantly greater for innovative firms.

Our results also indicate that the positive impact of a decrease in stock illiquidity on firm value is stronger in the sample of innovative firms with stronger incentive contracts for managers. This is consistent with the notion that these incentive contracts add more value when the stock is more liquid and its price better reflects the firm's value and manager's effort/contributions. This is especially true for innovative firms, where managers' actions may be harder to monitor. The value gain to innovative firms from improved stock liquidity could come from several sources: For instance, greater liquidity could decrease the cost of external financing, improve the functioning of incentive contracts, and/or enhance monitoring by large shareholders, among other possibilities. An important question that arises - and has broad policy implications - is whether the enhanced liquidity also tends to encourage innovation. We explore this by examining the impact of exogenous liquidity changes, such as those around stock price decimalization, on future patent applications by firms as well as citations of granted patents. Our finding is that exogenous liquidity improvements tend to be followed by a significant increase in innovative activity. These findings are quite different from Fang, Tian, and Tice (2012), who report an adverse effect of liquidity on future innovation. The differences are the direct result of using different regression specifications, in particular, the inclusion of firm characteristics such as past innovative activity in our specification. As we explain later, we believe our specification to be far more appropriate and robust. 
Overall, our results show how the business and technological needs of firms can affect their financing decisions as well as the various actions that can support such financing arrangements. Our paper makes several contributions to the corporate finance literature. First, we provide evidence on the firms' ability to influence and improve their stock liquidity. Although it has been argued in the literature that firms can and should improve their stock liquidity, the evidence has been lacking so far. As a result, stock liquidity is often regarded as being exogenously determined. Our results show that firms do care about the level of their liquidity and clearly take deliberate steps to improve it, especially when maintaining a higher stock liquidity is crucial for them. In this respect, our findings are related to those reported by Balakrishnan et al. (2011), who also conclude that managers can actively influence the liquidity of their shares. They show that managers provide more earnings guidance after the loss of public information producers (analysts) following brokerage-firm closures.

Second, our paper identifies many actions taken by firms that help with maintaining or improving stock liquidity. As such, our paper is related to many existing papers in the literature. For example, our paper is related to the literature on the relation between information disclosure and the stock liquidity as well as cost of capital (Diamond and Verrecchia, 1991). We show that managers of innovative firms are more likely to provide earnings guidance, and thereby, reduce their stock illiquidity. The literature on the liquidity effects of stock splits has been inconclusive as there is evidence that stock splits lead to an increase in liquidity (Dennis and Strickland, 2003) which is temporary (Lakonishok and Lev, 1987) or even decrease liquidity (Copeland, 1979). Our evidence suggests that stock splits, when instrumented by the propensity of stock-splits in the industry, result in a lower illiquidity for innovative firms. Kothare (1997) and Eckbo et al. (2000), among others, have shown that SEOs improve stock liquidity, as reflected in narrower bid-ask spreads subsequent to the public offering. We add to this literature by showing that SEOs lower stock illiquidity; in addition, we show that innovative firms are more likely to do SEOs.

Third, our findings are generally in line with the predictions of Holmström and Tirole (1993) that equity-based compensation contracts are most useful when the stock is more liquid. Their claim is that incentive contracts can induce managers to improve stock liquidity - which, in turn, 
renders the incentive contracts more effective since the efforts of the manager are better reflected in prices of a liquid stock. The findings in our paper on the positive impact of liquidity for corporate performance and innovative activity have potential policy implications. For instance, regulatory actions that encourage trading of stock and/or make it easier to raise equity capital could have a significant positive impact - more than may have been recognized - on innovative activity and overall economic growth.

The rest of the paper is structured as follows. We develop our empirical predictions in the next section and describe the data in Section 3. Section 4 presents evidence on innovative firms having greater stock liquidity and Section 5 shows the specific actions that these firms take in order to maintain or improve their stock liquidity. In Section 6, we show the characteristics of debt issued by firms that have more liquid stock and also show that the role of monitoring shifts to equity-holders. Section 7 shows that the marginal value impact of an increase in liquidity is higher for innovative firms and that an improvement in liquidity is generally related with an increase in innovative activity. Concluding remarks are made in Section 8.

\section{Testable Hypotheses}

Drawing upon the arguments made in the section above, we hypothesize that firms take actions that can help them control or at least influence the level of their stock liquidity. To test this, we focus on a set of firms that are expected to most value stock liquidity. Specifically, our argument is that innovative firms produce unique products and have assets with lower collateral values, which lowers their ability to raise debt. As a result, innovative firms may be compelled to rely primarily on equity markets for their external capital requirements. This suggests that innovative firms would value stock liquidity more than other firms that can access alternative sources of capital, such as debt, more easily. This leads us to posit our first testable hypothesis:

Hypothesis 1 (H1): Innovative firms have greater stock liquidity, controlling for industry and other firm characteristics; but less so when the firm has access to alternative sources of capital.

We build on the notion that firms can influence the level of their stock liquidity. Given their 
reliance on the equity market for capital, we argue that innovative firms will take steps that make it easier to access equity capital markets. Specifically, our second testable hypothesis is that:

Hypothesis 2 (H2): Innovative firms will take deliberate actions that are known to improve stock liquidity.

Due to the strong preference of innovative firms for liquidity, we expect that a marginal improvement in liquidity would be more valuable for these firms. Therefore, our third testable hypothesis is:

Hypothesis 3 (H3): The impact of a marginal increase in liquidity on value (Tobin's Q) would be greater for innovative firms.

We take these hypotheses and other related predictions to data and test them in a large sample of public firms. We describe our data sample next.

\section{Data and Description of Variables}

We draw our data from a variety of sources. We start with the accounting information for all available firms in Compustat from 1990 to 2006. After matching these with stock price information from $C R S P$, we are left with 12,172 firms and 82,460 firm-year observations. The main dependent variable that we analyze is the firm's stock liquidity and the independent variable of interest is the firm's innovation intensity. We describe these and other variables in detail below.

We collect the number of patents and citations from the NBER Patent Data Project. ${ }^{6}$ Information on listed options is obtained from OptionMetrics, which provides options data from 1996-onwards. We further match the sample with earnings guidance data from First Call that provides information on earnings guidance from 1994-onwards. Before conducting the empirical analyses, we winsorize all the variables at 1st and 99th percentile so as to minimize the impact of outliers on our findings, without losing a significant portion of the sample.

\footnotetext{
${ }^{6}$ The data are downloaded from https://sites.google.com/site/patentdataproject/Home/downloads.
} 


\subsection{Measures of Stock Liquidity}

Our main dependent variable of interest is the firm's stock liquidity. Although our intention is to measure the stock's liquidity, the commonly used measures in the literature in fact measure illiquidity. We follow the convention and, thus, adopt four different measures of illiquidity in our analysis. The first measure is Amihud's (2002) Illiquidity ratio. It is defined as $\ln \left(A v g I L L I Q \times 10^{8}\right)$, where AvgILLIQ is an yearly average of illiquidity, which is measured as the absolute return divided by dollar trading volume:

$$
\operatorname{AvgILLIQ}_{i, t}=\frac{1}{\text { Days }_{i, t}} \sum_{d=1}^{\text {Days }_{i, t}} \frac{\left|R_{i, t, d}\right|}{\operatorname{DolVol}_{i, t, d}},
$$

where $D a y s_{i, t}$ is the number of valid observation days for stock $i$ in fiscal year $t$, and $R_{i, t, d}$ and $\operatorname{DolVol}_{i, t, d}$ are the daily return and daily dollar trading volume, respectively, for stock $i$ on day $d$ of fiscal year $t$. This measure reflects the average stock price sensitivity to one dollar trading volume. Higher AvgILLIQ is interpreted as lower stock liquidity.

The second measure is the yearly average of monthly trading turnover, which is calculated as:

$$
\text { Turnover }_{i, t}=\frac{1}{12} \sum_{m=1}^{12} \frac{\text { Vol }_{i, t, m}}{\text { Shrout }_{i, t, m}}
$$

where $V_{o l} l_{i, t, m}$ and $S h r o u t_{i, t, m}$ are the shares traded and number of shares outstanding of firm $i$ in month $m$ of fiscal year $t$. In our analysis, we use Negative Turnover, which is simply the negative of Turnover calculated above and it thus measures the stock's illiquidity instead of liquidity.

The third measure is the yearly average of daily bid-ask spread:

$$
\text { Bid }- \text { Ask } \text { Spread }_{i, t}=\frac{1}{\text { Days }_{i, t}} \sum_{d=1}^{\text {Days }_{i, t}} \frac{A s k_{i, t, d}-\text { Bid }_{i, t, d}}{\left(A s k_{i, t, d}+\text { Bid }_{i, t, d}\right) / 2}
$$

where $D_{a y s} s_{i, t}$ is the number of valid observation days for stock $i$ in fiscal year $t$, and $A s k_{i, t, d}$ and $B i d_{i, t, d}$ are the closing ask and bid prices of stock $i$ on day $d$ of fiscal year $t$. Higher Bid-Ask Spread is interpreted as lower stock liquidity.

The fourth measure is the Probability of Informed Trading (PIN), which is proposed by Easley, Kiefer, O'Hara, and Paperman (1996) as a proxy for informed trading. We directly obtain the PIN measure for all NYSE and Amex common stocks over 1990-2001 from Søren Hvidkjær's website. ${ }^{7}$

\footnotetext{
${ }^{7}$ http://sites.google.com/site/hvidkjaer/data.
} 
Besides these dependent variables, we also analyze a host of other dependent variables that are used to bolster the main results. For ease of flow, we define those additional dependent variables when we describe the corresponding tests in the later sections.

\subsection{Identifying Innovative Firms}

As described above, we focus on innovative firms in order to test our hypotheses regarding the firms' influence on their stock liquidity. We use three main proxies for identifying firms as innovative and then further confirm the results with an additional (fourth) measure. The first firm characteristic that we use to identify innovative firms is the expenditure on $\mathrm{R} \& \mathrm{D}$. We define $R \mathscr{E} D$ as the ratio of R\&D expenses to lagged assets; we assume $R \mathscr{E} D$ to be zero if the firm's R\&D expense is missing in Compustat. Two other related measures of innovation are the number of patents granted to the firm and the citations generated by these patents. Data on patent-grants and citations are collected from the NBER patent database; these data correct for the truncation bias whereby older patents receive more citations. ${ }^{8}$ We define Log Patents as the logarithm of one plus the number of patents divided by hundred and Log Citations as the logarithm of one plus the number of citations (excluding self-citations) for the granted patents divided by hundred. (We divide the patents and citations by hundred to obtain coefficients of reasonable magnitude.) We also construct an "innovation index" using the principal components of these three variables; it is calculated as:

$$
\text { Innovation Index } x_{i, t}=\frac{0.3519 \times R \& D_{i, t}+0.6620 \times \text { Log Patents }_{i, t}+0.6618 \times \text { Log }_{\text {Citations }} \text { Pit, }}{100}
$$

Before constructing this Index, the three individual components are winsorized at the 1st and 99th percentiles and standardized so that they each have a zero mean and standard deviation equal to one. In addition to these measures of innovation, we also confirm our main results using Advertising as an alternative characteristic to identify firms producing unique goods. It is defined as the ratio of advertising expenses to lagged assets.

\footnotetext{
${ }^{8}$ A detailed description of these data and the bias-correction method can be found in Hall, Jaffe, and Trajtenberg, 2001.
} 


\subsection{Firm Characteristics}

We control for a number of firm characteristics that are known to be related to stock liquidity. Larger and older firms are likely to have greater liquidity; we control for size with Log Assets, which is the natural logarithm of total assets, and for the Firm's Age, which is the number of years since the firm first appeared in CRSP Daily database. Firms that rely more heavily on debt and less on equity will have lower liquidity; we control for the firm's Leverage, which is defined as the sum of long term debt and debt in current liabilities divided by total assets. Firms with more transparent assets on the balance sheet will have more liquid stock; we proxy for this with Cash and Tangibility, where the former is the ratio of cash and short term investments to lagged assets while the latter is the ratio of net property, plant, and equipment to total assets. Firms on the NYSE stock exchange tend to have greater stock liquidity; to that end, we include the NYSE Dummy, which is a binary variable that equals one if the firm is listed on the NYSE, and zero otherwise. We also control for the firm's growth opportunities with Tobin's $Q$ and operating performance with $R O A$. The former is the sum of total assets and the difference between market value and book value of common equity, divided by total assets; the latter is the ratio of earnings before extraordinary items to lagged assets. Finally, we control for Return Volatility, which is the standard deviation of daily stock returns over the fiscal year.

We also employ some additional firm-specific control variables in tests using dependent variables other than stock liquidity; these control variables are defined along with the description of the corresponding tests in later sections. Definitions of all the variables are summarized in the Appendix. We winsorize all variables at the 1st and 99th percentiles and present the summary

statistics in Table 1. These statistics are based on the regression sample and, therefore, require that all the variables be non-missing simultaneously. 


\section{Innovative Firms and Their Stock Liquidity}

\subsection{Evidence on the Stock Liquidity of Innovative Firms}

We start by first documenting the results obtained from testing the main premise of this paper that, innovative firms will have greater stock liquidity because it is difficult for them to raise capital in debt markets. Following the convention in the literature on stock liquidity, we use measures of illiquidity as dependent variables, and expect innovative firms to have lower illiquidity. Given that our prediction is cross-sectional, we test the following random-effects model:

$$
\text { Stock Illiquidity }_{i, t+1}=\alpha_{1}+\beta_{1} \text { Innovativeness }_{i t}+\gamma_{1}{ }^{\prime} \text { FIRM }+\lambda_{i}+\phi_{j}+\psi_{t}+\epsilon_{i, t+1} \text {. }
$$

Stock Illiquidity and Innovativeness are proxied by the variables described above in Section 3, and FIRM refers to the firm-specific control variables. $\lambda_{i}$ corresponds to firm $i$ 's random-effects while $\phi_{j}$ and $\psi_{t}$ represent dummies for industry $j$ and year $t$, respectively. Results obtained from estimating equation (1) using the four different measures of Stock Illiquidity are presented in Table 3. Specifically, we use Illiquidity, Negative Turnover, Bid-Ask Spread, and PIN as the dependent variable in Panels A-D, respectively. In all four Panels of Table 3, we measure the firm's innovativeness with $R \mathscr{E} D$, Log Patents, Log Citations, and the Innovation Index in columns (1)-(4), respectively. For brevity, we do not report the coefficients on the control variables in Panels B-D.

The results are consistent with our predictions and show that innovative firms have significantly lower stock illiquidity (or, equivalently, higher stock liquidity). Except when using PIN in Panel D, the estimated coefficients on innovativeness are statistically significant; in fact, all the coefficients on innovativeness across Panels A-C are mostly significant at the $1 \%$ level. The estimated coefficients are also economically large - e.g., the coefficient on $R \& D$ in column (1) of Panel A suggests that a 10 percentage point increase in $R \mathscr{E} D$ is associated with a $7.4 \%$ lower Illiquidity. We find similar results using the other dependent variables; for instance, a $10 \%$ increase in $R \mathscr{E} D$ is associated with a $10.8 \%$ (10.5\% and 4.2\%) lower Negative Turnover (Bid-Ask Spread and PIN, respectively). Therefore, overall, we find evidence in support of the claim that innovative firms have higher stock liquidity. 


\subsection{Robustness Checks}

Our results are robust to using Advertising instead of Innovativeness in equation (1). As mentioned earlier, firms that invest more in advertising are more likely to produce unique products; due to the lack of collateralizable assets, such firms are less able to sustain a higher leverage ratio (Titman and Wessels, 1988). Therefore, we argue that firms which invest more in advertising are also likely to value stock liquidity more than other firms. We find a strongly negative relation between the level of advertising and the firm's stock illiquidity; it is statistically significant at the $1 \%$ level for all four measures of illiquidity. The results are also economically strong - e.g., a 10\% increase in Advertising is associated with an $8.8 \%$ lower Illiquidity. The effects are similarly large when using the other three measures of illiquidity. We leave these results unreported for conserving space. ${ }^{9}$

Next, we re-estimate the model (1) with firm fixed effects. This helps us control for all the time invariant firm-specific effects and we thus estimate the innovativeness-illiquidity relationship within firms. The results using Illiquidity as the dependent variable are reported in Panel A of Table 4. The estimated coefficients on all four proxies of the firm's innovativeness are significant at the $1 \%$ level; while all the control variables shown in Panel A of Table 3 are included, their coefficients are not reported for brevity. Although our prediction is cross-sectional, this test shows that even over time within firms, there is evidence of a negative relation between innovativeness and stock illiquidity.

In another robustness check, we re-estimate model (1) with joint fixed effects for industry and year (i.e., including industry-times-year dummies instead of including them separately). We do this because time effects can have a heterogeneous impact on different industries. Results using this alternative specification are reported in Panel B of Table 4; again for brevity, we only show the results based on our main dependent variable - Illiquidity. The negative association between innovativeness and illiquidity remains significant even after controlling for the industry-specific year effects.

To further test the robustness of the main results reported in Table 3, we test the same model (1)

\footnotetext{
${ }^{9}$ These results can be made available upon request.
} 
across different industry subsamples. Following the classification based on SIC codes, we estimate the regression for firms in the following sectors: agriculture, forestry and fishing (SIC between 100 and 999); mining (SIC between 1000 and 1499); construction (SIC between 1500 and 1799); manufacturing (SIC between 2000 and 3999); transportation, communication, electric, gas and sanitary services (SIC between 4000 and 4999); wholesale trade (SIC between 5000 and 5199); retail trade (SIC between 5200 and 5999); finance, insurance, and real estate (SIC between 6000 and 6799); and services (SIC between 7000 and 8999). Panel C of Table 4 shows that the relationship between innovativeness and illiquidity remains significantly negative in most of the sectors - the relationship does not hold in the mining, wholesale, and retail sectors. This is consistent with our arguments because there is little innovation undertaken in these sectors.

\subsection{When Innovative Firms Have Access to Other Sources of Capital}

We have argued that innovative firms have a need for greater stock liquidity because they primarily rely on equity markets for their financing. As a corollary, if an innovative firm is less reliant on stock markets for its capital needs, then the need for greater stock liquidity would be mitigated. Similarly, if the firm is not financially constrained, then the need to raise capital in equity markets, and consequently the importance of greater stock liquidity, would be diminished. We test these arguments using the following random-effects regression model:

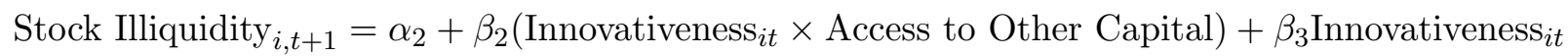

$$
\left.+\beta_{4} \text { (Access to Other Capital }\right)+\gamma_{2}^{\prime} F I R M+\lambda_{i}+\phi_{j}+\psi_{t}+\epsilon_{i, t+1} .
$$

We use the same four measures of stock illiquidity as above - Illiquidity, Negative Turnover, BidAsk Spread, and PIN in columns (1)-(4), respectively, of each Panel in Table 5. For brevity, we only use the Innovation Index as our measure of innovativeness although our results are robust to using the individual components of this index. We predict that even though there is a negative relation between innovativeness and illiquidity, this relationship should be weaker when the firm has access to other capital (i.e., even if $\beta_{3}$ is negative, $\beta_{2}$ should be positive).

In Panels A and B of Table 5, our proxy for Access to Other Capital reflects the firm's access 
to public debt markets. Specifically, we use Public Debt Dummy in Panel A while in Panel B, we use High Ratings Dummy. The former is an indicator variable that is equal to one if the firm has a long-term $\mathrm{S} \& \mathrm{P}$ credit rating and the latter is an indicator variable for the firm's $\mathrm{S} \& \mathrm{P}$ credit ratings being higher than or equal to "A-". Dass, Kale, and Nanda (2011) have shown that firms with greater market power are able to extract more trade credit from their partner firms along the supply chain. In that vein, we use the Market Power Dummy as the proxy for Access to Other Capital in Panel C of Table 5. Market Power Dummy is a binary variable that equals to one if the firm's market power is higher than the sample median, and zero otherwise; market power is captured by the Lerner Index, which is proxied by the firm's price-to-cost margin (Waterson, 1984; Tirole, 2002). Finally, in Panel D, we use dividend payments as the proxy for firms' financial constraints - a firm's ability to pay dividends is a sign of less severe financial constraints. We characterize this with the binary variable Dividend Dummy that equals one if the firm pays dividends to common or preferred stockholders in the fiscal year; it equals zero otherwise.

We interact these four proxies for Access to Other Capital with Innovation Index. As before, FIRM, $\lambda_{i}, \phi_{j}, \psi_{t}$, and $\epsilon_{i t}$ represent firm-specific control variables, firm $i$ 's random-effects, dummy for industry $j$, and dummy for year $t$, respectively. Coefficients on the control variables are not reported to keep the tables concise. The results in Table 5 confirm our predictions and show that the illiquidity of innovative firms is lower, but less so when they have access to other sources of capital or when they are less financially constrained. For instance, in Panel B, the estimated coefficient on the interaction term is positive and significant at the $1 \%$ level in all four columns while the estimated coefficient on innovativeness is negative and mostly significant at the $1 \%$. In terms of the economic magnitude, the coefficient in column (1) of Panel B suggests that a one standard deviation increase in the Innovation Index is associated with a $5.7 \%$ lower Illiquidity for firms with no credit ratings or credit ratings lower than "A-". However, Illiquidity is only $3.0 \%$ lower for firms with S\&P credit rating equal to or higher than "A-". We generally obtain similar results with other measures of illiquidity as well as proxies for less reliance on equity markets in all panels of Table 5. Overall, the evidence presented in Tables 3-5 supports the hypothesis H1 
that innovative firms have greater stock liquidity, but less so when they are less reliant on equity markets for their capital needs.

\section{How Do Firms Influence Their Stock Liquidity?}

\subsection{Innovative Firms Take Steps to Improve Their Stock Liquidity}

So far, we have established a negative correlation between the innovativeness of firms and their stock illiquidity. In this section, we argue that since innovative firms prefer a more liquid stock, they would take deliberate steps to improve their stock liquidity. We test this hypothesis by identifying actions that are known to improve liquidity, and then checking whether innovative firms are more likely to take these actions. The empirical model that we test can be represented as follows:

$$
\text { Liquidity-improving Actions } \text { A }_{i, t+1}=\alpha_{3}+\beta_{5} \text { Innovativeness }_{i t}+\gamma_{3}{ }^{\prime} \text { FIRM }+\lambda_{i}+\phi_{j}+\psi_{t}+\epsilon_{i, t+1} \text {. }
$$

The results are presented in various Panels of Table 6. Throughout, we only report the coefficients of the main independent variables even though the remaining control variables are included in the estimation.

The first liquidity-improving action that we analyze is Guidance, which measures managerial guidance for future earnings. It is calculated as the logarithm of one plus the frequency of earnings guidance forecasts provided by the management in the given fiscal year. Information asymmetry between market participants and a general lack of informational transparency is one reason for greater stock illiquidity. Therefore, the firm can partially improve its liquidity by releasing more information to the market. As such, innovative firms, with the aim to improve informational transparency, would be more likely to provide information more frequently to the market. We report the results using this dependent variable in Panel A of Table 6. As before, we proxy for the firm's innovativeness with $R \mathscr{E} D$, Log Patents, Log Citations, and the Innovation Index in columns (1)-(4), respectively. We find evidence in support of our prediction. Specifically, there is a positive relation between innovativeness and the frequency of earnings guidance by the management. Coefficients on all four measures of innovativeness are statistically significant at the $1 \%$ level. These results are also economically significant - e.g., one standard deviation increase in innovation index is associated 
with $3 \%$ increase in the frequency of earnings guidance.

The firm's stock liquidity will also be higher if the investor base is wider. To that end, the second liquidity-improving action that we analyze is Stock Splits because splitting the stock may make the stock accessible to more investors, which could enhance the stock's liquidity. We define the dependent variable Stock Splits as a binary variable that equals one if there is a stock split in the given fiscal year; it equals zero otherwise. The level of stock price is the most important determinant of a firm's decision to split its stock; so, the effect of innovativeness on stock splits must be conditional on stock price levels. To estimate this conditional effect of innovativeness from equation (3), we interact the stock price with four different dummy variables corresponding to the four proxies of innovativeness. ${ }^{10}$ We also control for the Stock Price, which is defined as the firm's closing stock price at the end of prior fiscal year. The results are presented in Panel B of Table 6. Our results show that, conditional on stock prices, measures of innovativeness are positively associated with the probability of stock splits. All the estimated coefficients on the interaction terms are positive and mostly significant statistically. The results are also economically meaningful. For instance, conditional on stock prices, the marginal effect of a dollar increase in stock price on the likelihood of a stock split is $7.5 \%$ higher for patenting firms than non-patenting firms. As expected, the base effect of the level of stock price is strongly positive.

Further utilizing the link between a wider investor base and greater stock liquidity, we analyze another action that the firm can take in order to widen its investor base - the firm can issue more equity! Specifically, a wider investor base can also be achieved by making more equity shares available to potential investors. As such, we analyze the likelihood that the firm conducts a seasoned equity offering (SEO). The dependent variable SEO Dummy is a binary variable that equals one if the firm does an SEO in the given fiscal year, and it is zero otherwise. Our prediction is that innovative firms, due to their desire for a more liquid stock, are more likely to undertake an SEO. The results from the estimation of equation (3) with dependent variable SEO Dummy are presented

\footnotetext{
${ }^{10}$ These dummy variables indicate whether the corresponding variable is positive or zero. RED Dummy equals one if the firm invests in R\&D, and equals zero otherwise. Patent Dummy equals one if the firm has patents, and equals zero otherwise. Citation Dummy equals one if the firm's patents have at least one citation, and equals zero otherwise. Innovation Index Dummy equals one if the firm's Innovation Index is positive; the dummy equals zero if the index is negative.
} 
in Panel $\mathrm{C}$ of Table 6. Using the same four measures of innovativeness that we have used earlier, we find across columns (1)-(4) that innovativeness positively affects the likelihood of an SEO. The estimated coefficients on innovativeness are significant at least at the $5 \%$ level. They also reflect a meaningful impact in economic terms - specifically, one standard deviation increase in $R \mathscr{E} D$ is associated with an $8.6 \%$ increase in the likelihood of a SEO.

With respect to the SEO, the firm can also take some additional steps that can enhance the informational transparency in the market. For instance, the firm can choose a more "reputed" underwriter for its equity offerings. More reputed underwriters can certify the issuer's quality, provide better access to a wider base of potential investors, will be able to create broader interest in the equity offering, and are also known to provide price support. As a result, innovative firms are more likely to use the services of a reputed underwriter. For testing this claim, we define the dependent variable Reputed Underwriter as a binary variable that equals one if the firm hires a more reputable underwriter for the SEO. We classify an underwriter as "reputed" if its ranking is 8 or higher on the 0-to-9 scale in Jay Ritter's IPO Underwriter Reputation Rankings (1980-2009). ${ }^{11}$ The results, reported in Panel D of Table 6, are consistent with this prediction as the estimated coefficients on all measures of innovativeness across columns (1)-(4) are positive and significant at the $1 \%$ level. The coefficient in column (1) suggests that one standard deviation increase in $R \& D$ is associated with a $4.3 \%$ increase in the likelihood of using a reputed underwriter.

Finally, in Panel E of Table 6, we analyze whether innovative firms are more likely to have options listed on their stock. Although the decision to list options is made by the exchange (Mayhew and Mihov, 2004), their decision is predicated on factors such as trading interest in the underlying stock. Hence, actions taken by an innovative firm to enhance liquidity by, for instance, seeking a wider investor base and improving its information environment, will also likely increase trading interest in the stock - and, thus, make it a more attractive candidate for the exchange listing of its options. The listing, in turn, could further improve the stock's liquidity. We test for option listing by using a dependent variable denoted Listed Options, which is a binary variable that equals one if

\footnotetext{
${ }^{11}$ We obtain these from Jay Ritter's website, http://bear. warrington.ufl.edu/ritter/ipodata.htm.
} 
the firm has options traded on its stock in the given fiscal year; it is zero otherwise. We find that, indeed, innovative firms are more likely to have options traded on an exchange. The estimated coefficients on innovativeness are positive and significant at the $1 \%$ level across all four columns. The effect is also economically large - e.g., one standard deviation increase in $R \mathscr{E} D$ is associated with an $8.1 \%$ increase in the likelihood of options being listed on the firm's stock.

Overall, the evidence presented in Panels A-E of Table 6 suggests that innovative firms, indicative of the value they attach to stock liquidity, are more likely than other firms to take deliberate actions that can improve their stock liquidity. In a robustness check using Advertising instead of measures of innovation, we confirm the main results - firms that spend more on advertising are also more likely to take liquidity-improving actions. The results are mostly statistically significant and also economically large; for instance, a 10 percentage point increase in Advertising is associated with $8.8 \%$ higher frequency of earnings guidance from the management about future earnings. We leave these results unreported for brevity.

\subsection{The Effect of Innovative Firms' Actions on Their Stock Illiquidity}

Although we have shown above that innovative firms take various steps that can improve the informational environment and encourage trading in their stocks, in this section we explicitly test whether these actions yield the desired result in terms of improved liquidity. However, the liquidity as well as the propensity to take these actions, are both positively affected by the level of firm's innovativeness. Therefore, we pursue an instrumental variables regression methodology to better identify the effect of firms' actions on liquidity-improvement. With Illiquidity as the dependent variable and using industry-level instruments for Guidance, Stock Splits, and SEO Dummy, we test whether these specific actions are associated with a lower stock illiquidity. ${ }^{12}$ The model that we

\footnotetext{
${ }^{12}$ We do not use Reputed Underwriter because it is defined only within the much-smaller sample of SEOs. We also do not use Listed Options because, as indicated above, it is not under the firm's direct control. Rather, the listing of options is an indirect result of the firm improving its information environment and generating enough trading interest.
} 
estimate can be represented as:

$$
\begin{aligned}
\text { Illiquidity }_{i, t+1} & =\alpha_{4}+\beta_{6}\left(\text { Instrumented }_{\text {Actions }} i t\right)+\beta_{7}\left(\text { Innovation Index }_{i t}\right) \\
& +\gamma_{4}{ }^{\prime} \text { FIRM }+\lambda_{i}+\phi_{j}+\psi_{t}+\epsilon_{i, t+1} .
\end{aligned}
$$

The variables used in this regression are the same as those defined above, including the randomeffects as well as industry and year dummies. We instrument Guidance with its median value among all the other firms in the corresponding Fama-French 48-industry. Since Stock Splits and SEO Dummy are indicator variables, we rely on the respective mean values (instead of the medians, which are zero) in the corresponding Fama-French 48-industry.

All four regressions reported in Table 7 are exactly-identified as we rely on a single instrument that is most likely to be associated with the corresponding firm-action but is unlikely to be directly related with an individual firm's stock illiquidity. The advantage of using exactly-identified instrumental variable regressions is that the choice of our instrument is strongly motivated by economic arguments and does not rely on statistical tests that are necessary in over-identified regressions (Roberts and Whited, 2011).

As the first stage regression estimates in the bottom panel of Table 7 show, the chosen instruments are strongly significant (at the $1 \%$ level) in predicting the firm's actions. More importantly, we find that these instrumented actions have a strongly negative relation with the stock's illiquidity even after controlling for the firm's innovativeness (with Innovation Index) and other firm characteristics (estimated coefficients for the latter are not reported). These results show that the deliberate actions taken by innovative firms do improve their stock liquidity. These actions are useful in either improving the informational environment surrounding the firm's stock or widening the investor base. This eventually helps enhance the firm's stock liquidity, which makes raising equity capital easier for innovative firms and also lowers their cost of capital.

Overall, the evidence presented in this section supports our hypothesis H2 that innovative firms will take steps to improve their stock liquidity. 


\section{Other Effects of Innovative Firms' Greater Stock Liquidity}

\subsection{Debt of Innovative Firms}

So far, we have analyzed the stock liquidity of innovative firms, arguing that they prefer liquidity because issuing debt is more difficult or costly due to the nature of their assets and investments. In this section, we analyze how this need for stock liquidity interacts with the type of debt that innovative firms raise. First, we argue that the attempts of innovative firms at mitigating the information asymmetry in the stock market can also benefit them in the debt markets. Second, the firm can also lower the information asymmetry by generating information in the public debt markets. And third, due to their lower leverage ratio, innovative firms will be received favorably by the creditors when they do issue debt. We test these arguments using the following empirical model:

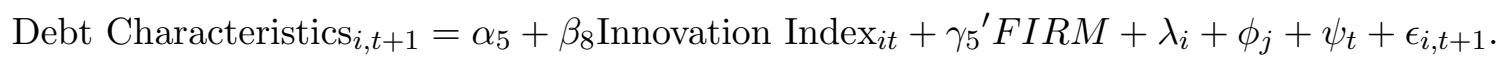

We present the results from this model in Table 8. In Panel A, the dependent variable is Public Debt Dummy, as defined in Table 5 above. We estimate the coefficients using a Probit model with firm random effects, denoted by $\lambda_{i}$ in equation (5). In Panel B, the dependent variable is Credit Rating, which is an ordinal variable categorizing the firm's long-term credit rating from S\&P. Specifically, firms without any rating are grouped into the base category (denoted by 0 ) and the remaining firms are grouped into six categories (ranging from 1 for $\mathrm{CCC}$ or below through 6 for AA and above). In this case, we estimate the model using an Ordered Probit regression; as such, we cannot control for the firm random effects. In Panels $\mathrm{C}$ and $\mathrm{D}$, we analyze the characteristics of private debt taken by innovative firms. In Panel C, the dependent variable Covenant Dummy equals one if the firm has at least one accounting-based quantitative financial covenant in the loan(s) borrowed in the given fiscal year, and it is zero otherwise. In Panel D, the dependent variable Number of Covenants is the average number of covenants in the loan(s) issued in the fiscal year. We obtain these data on bank loan characteristics from Thomson Reuter's Dealscan database. ${ }^{13}$ Note that the sample of

\footnotetext{
${ }^{13}$ Note that all bank loans have qualitative/positive covenants (e.g., requiring the borrower to obtain unqualified audit reports); these are part of the boilerplate language of loan contracts. The covenants recorded in Dealscan are
} 
banks loans do not constitute a panel of firms across years. Due to this, we do not control for firm random effects in Panels $\mathrm{C}$ and D; instead, we estimate equation (5) using a pooled regression using the Probit model in Panel $\mathrm{C}$ and the Ordered Probit in Panel D. As before, we use R\&D, Log Patents, Log Citations, and Innovation Index as our measure of innovativeness in columns (1)-(4), respectively, of all the Panels in Table 8. Coefficients of the control variables are left unreported throughout the table.

We find that although the coefficient on $R \mathscr{E} D$ is usually statistically not different from zero, the other three estimated coefficients on innovativeness in columns (2)-(4) are significant at least at the $5 \%$ level in all four Panels. These results suggest that innovative firms are: more likely to have a long-term $\mathrm{S} \& \mathrm{P}$ credit rating, more likely to have a higher rating, conditional on having a long-term credit-rating. They are also less likely to have restrictive covenants in their loans and likely to have fewer restrictive covenants (if at all) in their loans. These findings generally support the above predictions and the overall message in Table 8 is that innovative firms are better-quality borrowers either because they are informationally more transparent, subject to market discipline, and/or have lower leverage ratios. Finally, our findings are also consistent with the notion that because of the nature of their investments, innovative firms prefer financial contracts that are less limiting. This is not only reflected in their greater reliance on equity capital but also in the fewer covenants that are included in their loan contracts.

\subsection{Who Monitors the Innovative Firms?}

Banks typically play an important role in monitoring borrowers. However, innovative firms have lower leverage ratios and, as our evidence above shows, also tend to have fewer restrictive covenants in their bank loans. If so, how are managers in these firms monitored? We argue that due to their reliance on equity capital, the onus of monitoring the managers lies with equity holders. Among all equity holders, institutional investors, and particularly block holders, have a greater stake and may be better at monitoring firms (Edmans and Manso, 2011). As such, we argue that innovative

only the accounting-based quantitative/restrictive covenants; these are imposed on top of the qualitative/positive covenants. 
firms are more likely to have blockholders and a greater institutional ownership. These firms should also incentivize their managers with more equity-based compensation contracts. This is optimal when the equity is more liquid as the effort of the manager can be better reflected in stock prices (Holmström and Tirole, 1993). We test these claims with the following regression model:

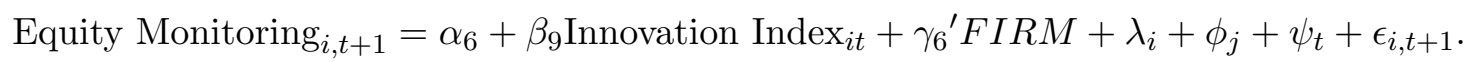

The estimates are reported in Table 9. We follow the same random-effects regression model as before, except our dependent variable is one of the following: Institutional Ownership in Panel A is the number of shares held by all the institutional investors in $13 F$, divided by total number of shares outstanding (obtained from CRSP). Blockholder Dummy in Panel B is a dummy variable that equals one if there is at least one blockholder that holds $5 \%$ or more of the firm's shares, and equals zero otherwise. Equity-Based Compensation in Panel C is the sum of options and restricted stock grants, divided by the CEO's total compensation. When analyzing the CEO's compensation, we also control for the CEO's Age, CEO's Tenure, CEO's Ownership, as well as Free Cash Flows, in addition to other firm characteristics already defined above. Free Cash Flows is the sum of net cash flow from operating activities and net cash flow from investing activities, divided by total assets.

As before, the measure of innovativeness is RED, Log Patents, Log Citations, or the Innovation Index in columns (1)-(4), respectively. Our results strongly support the predictions - we find that firm innovativeness is positively related with these equity-based measures and the estimated coefficients are mostly significant at the $1 \%$ level. A larger institutional ownership and greater likelihood of blockholders in innovative firms suggests that managers are more likely to be monitored by the equity-holders. The CEO's compensation contract is also more heavily equity-based, suggesting that the firm's board relies on equity prices for monitoring the manager's actions. Overall, this evidence is consistent with the notion that innovative firms rely less on debt capital and, therefore, the managers must be monitored by equity-holders instead of creditors. 


\section{Marginal Impact of an Increase in Stock Liquidity}

\subsection{Do Innovative Firms Benefit More From an Increase in Liquidity?}

In this section, we analyze the impact of a change in liquidity on the firms' value, and test whether the marginal impact of an improvement in stock liquidity on the value is larger for innovative firms. We have argued in our hypothesis $H 3$ that the positive impact of an increase in liquidity (or, correspondingly, the negative impact of an increase in illiquidity) should be marginally greater for innovative firms because of their reliance on equity markets and their greater need for liquidity. However, both the firm's value and its liquidity are influenced by its innovativeness. We address this endogeneity in several different ways, starting with the following instrumental-variable regression:

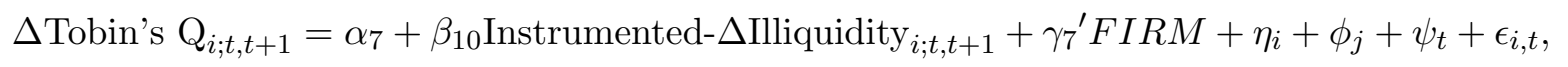

where $\eta_{i}$ represents the firm fixed-effects while the rest of the variables are same as those defined earlier. The change in the firm's stock illiquidity over the year $t$ to $t+1\left(\Delta\right.$ Illiquidity $\left._{i ; t, t+1}\right)$ is instrumented by the $(t, t+1)$ change in the median illiquidity of all other firms in the same FamaFrench 48-industry. As before, we argue that it is preferable to use only one instrument that is economically justifiable instead of choosing multiple instruments on statistical grounds (Roberts and Whited, 2011). We estimate this exactly-identified instrumental variable regression separately for the sample of more and less innovative firms. We categorize firms as more innovative if they make R\&D investments, produce patents, have citations on their patents, or have a positive Innovation Index. The firms that do not invest in $\mathrm{R} \& \mathrm{D}$, have no patents or citations, or have a negative Innovation Index are categorized as being less innovative. The results from this analysis of the two subsamples are presented in Table 10, and they show that the negative impact of an increase in illiquidity is larger in the case of more innovative firms.

Although the results in Table 10 support our prediction, we bolster these further by using two plausibly exogenous shocks to the firm's stock illiquidity. The general model that we test can be 
written as:

$$
\begin{aligned}
\Delta \text { Tobin's } \mathrm{Q}_{i ; t-1, t+1} & =\alpha_{8}+\beta_{11} \text { Illiquidity }_{i ; t-1, t+1} \\
& +\gamma_{8}{ }^{\prime} \text { FIRM }_{t-1}+\gamma_{9}{ }^{\prime} \Delta F I R M_{i ; t-1, t}+\phi_{j}+\epsilon_{i, t} .
\end{aligned}
$$

The first exogenous shock to stock liquidity is the decimalization of prices on US stock exchanges, which was started in earnest in early 2001 and was completed by April 2001. As Fang, Noe, and Tice (2009) have shown, the improvements in stock liquidity that occurred around exchange decimalization were accompanied by a corresponding increase in firm value. We extend their results by testing for whether the value impact of these liquidity linked increases is significantly larger for innovative firms - which we would expect if stock liquidity was, on the margin, more valuable for innovative firms.

To operationalize the test of model (8), we first calculate the change in firms' stock illiquidity from year 2000 to 2002, i.e., around the year stock prices were decimalized. The dependent variable $\Delta$ Tobin's $\mathrm{Q}_{i ; t-1, t+1}$ is a change in firm value measured over the years 2000-2002, while main explanatory variable is the change in stock illiquidity, $\Delta$ Illiquidity $_{i ; t-1, t+1}$. We also control for various firm characteristics with their levels prior to as well as changes in their values around decimalization; these are denoted by $F I R M_{t-1}$ and $\Delta F I R M_{i ; t-1, t}$, respectively. We again test the model in subsamples of more and less innovative firms; we classify firms as more or less innovative in the same manner as in Table 10 above. We report the results from this estimation in Panel A of Table 11. We expect $\beta_{11}$ in equation (8) to be negative and greater in magnitude among innovative firms. While the estimated $\beta_{11}$ is significantly negative at the $1 \%$ level in all columns, we find the effect to be greater among firms that are more innovative. Therefore, our evidence is consistent with our prediction that the marginal impact on firm value due to a change in liquidity is greater for innovative firms because they value stock liquidity more than other firms.

In Panel B of Table 11, we test the above model (8) with another exogenous shock that is known to improve stock liquidity for reasons unrelated to information asymmetry - addition of a stock to the S\&P 500 Index. The sample in this test consists only of those stocks that are added to the S\&P 500 Index at some point during our sample period. While the existing literature finds that 
the addition to $\mathrm{S} \& \mathrm{P} 500$ Index is associated with positive abnormal returns (e.g., Harris and Gurel, 1986; Shleifer, 1986; Lynch and Mendenhall, 1997) as well as an improvement in stock liquidity (e.g., Beneish and Whaley, 1996; Hegde and McDermott, 2003), our prediction is that the impact on value due to an increase in liquidity should be greater for innovative firms. We calculate the change in stock illiquidity and firm value over years $(t-1, t+1)$ for all sample firms added to the Index; $t$ denotes the year of their addition to the Index. Estimates from the model (8) are reported in Panel B of Table 11 and support the findings in Panel A. Specifically, we find that the estimated coefficients are significantly negative (at the $1 \%$ level) and greater in magnitude among the more innovative firms, but mostly statistically insignificant for the less innovative firms.

Next, we examine whether stock liquidity increases firm value more for those innovative firms that offer a larger equity-based component in the CEO's compensation. As discussed earlier, from the arguments in Holmström and Tirole (1993), stronger equity contracts would incentivize managers to boost firm liquidity as well as to put in more effort toward improving firm value. As we have seen above, innovative firms tend to have stronger incentive contracts; we now investigate whether the value impact of an exogenous liquidity increase is larger when the CEO has a stronger incentive contract. We test this by estimating a variant of model (8) where we analyze changes in liquidity due to stock price decimalization:

$$
\begin{aligned}
\Delta \text { Tobin's } \mathrm{Q}_{i ; t-1, t+1} & =\alpha_{9}+\beta_{12}\left(\Delta \text { Illiquidity }_{i ; t-1, t+1}\right) \times(\text { Incentives })+\beta_{13} \text { Incentives } \\
& +\beta_{14} \Delta \text { Illiquidity }_{i ; t-1, t+1}+\gamma_{10}{ }^{\prime} F I R M+\gamma_{11}{ }^{\prime} \Delta F I R M_{i ; t-1, t}+\phi_{j}+\epsilon_{i, t} .
\end{aligned}
$$

As in model (8), $\Delta$ Illiquidity $_{i ; t-1, t+1}$ is the change in liquidity surrounding the stock price decimalization in year $t$. Incentives measure the Equity-Based Compensation or Wealth-Performance Sensitivity. As described earlier, Equity-Based Compensation measures the equity and options portion of the CEO's compensation contract. Wealth-Performance Sensitivity is the dollar change in the CEO's wealth for a 100 percentage point change in firm value (Edmans, Gabaix, and Landier, 2009). We again perform the analysis on subsamples of firms based on whether they make R\&D investments, produce patents, have citations on their patents, or have a positive Innovation Index.

Table 12 presents the estimated coefficients of this test. Consistent with our prediction, we find 
that the negative impact of an exogenous increase in stock illiquidity on firm value is stronger in the sample of innovative firms that offer stronger incentive contracts to the managers. In Panel A, the coefficient on the interaction between $\Delta$ Illiquidity $_{i ;-1, t+1}$ and Equity-Based Compensation is negative and significant while it is positive (and sometimes significant) for non-innovative firms. This implies that while an increase in liquidity benefits all firms, innovative firms that offer greater managerial incentives tend to benefit more than non-innovative firms that also offer managerial incentives. We interpret this as being consistent with our prediction that innovative firms, whose assets are more opaque and managers' actions are harder to monitor, benefit more by designing compensation contracts with stronger incentives. The benefit is reflected in the greater value impact of an exogenous increase in stock liquidity due to stock price decimalization. Similar results are found in Panel B - the coefficient on the interaction between $\Delta$ Illiquidity $_{i ; t-1, t+1}$ and WealthPerformance Sensitivity is significantly negative for all firms but it is slightly larger in magnitude for innovative firms.

Overall, the results in Tables 10-12 support our working hypothesis H3 and show that the marginal impact of a change in stock liquidity on firm value is greater for innovative firms. These results lend further support to one of the main themes of our paper - that, innovative firms value stock liquidity more than other firms.

\subsection{Impact of Liquidity on Future Innovation}

The results so far indicate that exogenous increases in liquidity are accompanied by increases in firm value, especially when the firm is innovative. However, the value gain to innovative firms from improved stock liquidity could be due to different reasons. For instance, innovative firms have the incentives to mitigate informational opaqueness and, thus, enhance liquidity. Lesser informational asymmetry in financial markets about the firm would help decrease the cost of external financing, especially equity financing. Stock-based incentive contracts are also expected to be more effective when more information is contained in stock prices; this is particularly useful for innovative firms whose assets tend to be opaque and managers' actions can be harder to monitor. Another benefit is that the greater liquidity may attract institutional and other large shareholders, thus possibly 
improving the monitoring of managerial performance.

However, an important question is whether the positive impact of liquidity on firm value is achieved only through reductions in financing costs and agency costs or whether the benefits of improved liquidity are also derived from better investments, especially innovative activity. The relationship between stock liquidity and innovation is of particular interest to policy makers - the direction of this relationship would inform the debate on whether more stock market liquidity is desirable. We explore this vital question by examining the consequences of exogenous changes in illiquidity on future innovative activity. As above, we proxy for the change in illiquidity either with an instrumental variable or with an exogenous shock (specifically, stock price decimalization). We start with the following instrumental variable regression that includes firm and year fixed-effects:

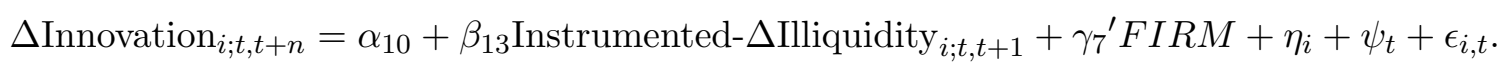

The control variables FIRM are the same as those defined earlier, $\eta_{i}$ represents the firm fixed effects, and $\psi_{t}$ represents time effects. The dependent variable $\Delta$ Innovation $_{i ; t, t+n}$ represents a change in either patent applications that are eventually granted over the next $n$ years or citations of patents that are applied for over the next $n$ years; we allow for $n$ to vary from 1 through $4 .{ }^{14}$ The independent variable of interest $\Delta$ Illiquidity is the change in illiquidity from year $t$ to $t+1$, and it is instrumented by the change over the same period in median Illiquidity of all the other firms in the same Fama-French 48-industry.

The results are presented in Panel A of Table 13, and indicate that an increase in liquidity has a positive effect on future innovation - both in terms of the number of eventually-granted patents applications (in columns (1)-(4)) and citations of patents (in columns (5)-(8)). The coefficients are statistically significant at least at the $5 \%$ level when $n$ is between two and four; the simultaneous effect of a change in liquidity on innovation (i.e., when changes in both liquidity and innovation are measured over $(t, t+1))$ has a similar sign, though it is not statistically significant.

\footnotetext{
${ }^{14}$ For instance, when $n=3$, we first calculate the logarithm of one plus the number of eventually-granted patent applications in years $t$ and $t+3$, and then take the difference between these two values. Similarly, for citations, we first calculate the the logarithm of one plus the number of citations of patents that are applied for in years $t$ and $t+3$, and then take the difference between these two values.
} 
Next, we test for the relation between changes in liquidity and future innovation using a variant of the above model (10). Instead of using an instrumented change in illiquidity (as in model (10) above), we examine the effect of liquidity changes around decimalization (i.e., over years 20002002 , denoted by $t-1, t+1$ ) on subsequent innovation. The dependent variables are the changes in patent applications or citations on eventually-approved patent applications; the changes in patent applications are measured from year $t-1$ to $t+1, t+2$, or $t+3$ ( $t$ denotes the year 2001 , i.e., the year of decimalization). In addition to the variables listed in model (10), we also include the lagged value (i.e., value in year 2000) of innovation as an additional control on the right-hand side. The purpose of controlling for the past innovative activity is to address the innate censoring in these data: firms with no patents at $t-1$ can only have a positive or no change in innovation; these are also the firms whose business strategy is unlikely to be organized around innovative activity. We therefore believe that accounting for the firms' past innovation is crucial in understanding the true effect of a liquidity-increase on innovation. The regression also includes changes over $(t-1, t+1)$ in the firm-level control variables that are used in Panel A.

The results presented in Panel B of Table 13 indicate that exogenous changes in liquidity tend to enhance the innovative activity of firms. We would like to point out that these findings are quite different from those of Fang, Tian, and Tice (2012), who document an adverse impact of a liquidity-increase (also surrounding decimalization) on future innovation. The difference between our studies can be ascribed to the use of different regression specifications and we believe that our specification is more appropriate. First, we are, indeed, able to replicate the findings in Fang et al (2012) but only if we do not include lagged levels of patent applications or citations. However, our analysis indicates that the changes around the year of decimalization in patent applications and citations are significantly negatively related with the corresponding lagged values - this suggests that more innovative firms saw a decline in their innovation around this time period. As we have mentioned above, this makes sense because the data are affected by the censoring due to firms that have not produced patents in year $t-1$. Hence, including these lagged values as a control variable is crucial, i.e., conditioning on the level of past innovative activity is important if we want to draw 
conclusions about the relationship between liquidity and innovation. Second, the years around decimalization 2000-2002 were years of economic slowdown (following the bursting of the "dot-com bubble"). This economic downturn specifically affected technology firms, thereby resulting in a decline in patent applications (and subsequently citations) around this period. Therefore, it is not surprising that the change in patent applications over this period is strongly related to prior level of patenting and not including lagged levels would bias the results. In fact, as noted above, when the lagged level of innovation is not included, we find that the estimated coefficient on illiquidity flips to a positive sign - which is the finding in Fang et al. (2012).

To further test for robustness of the results presented above, we estimate another variant of the model used in Panel B. For this, we construct dummy dependent variables that indicate whether changes in patent applications or citations are non-negative when measured from year $t-1$ to $t+1$, $t+2$, or $t+3$ surrounding the year $t$ of stock price decimalization. As before, the independent variable of interest is $\Delta$ Illiquidity from year $t-1$ to $t+1$. The results are presented in Panel C of Table 13. Although the estimated coefficients on $\Delta$ Illiquidity are not always statistically significant, the negative sign indicates that there is, indeed, a greater likelihood of an increase in innovative activity following an exogenous change in liquidity due to decimalization. Overall, the results presented in Table 13 seem to suggest that changes in liquidity lead to an increase in innovation.

\section{Conclusion}

In this paper, we study the liquidity choice of firms. Although many of the firm's actions are known to influence stock liquidity, the literature has largely viewed stock liquidity as being determined exogenously. We directly test for the firm's deliberate influence on its stock liquidity by focusing on a set of firms that are more likely to value stock liquidity due to their reliance on equity markets for much of their capital needs. We borrow from the literature on capital structure choice and argue that firms producing innovative products cannot maintain as high leverage ratios as other firms. This may either be due to the strategic externalities of their capital structure choice or simply 
due to the scarcity of collateralizable assets. The existing literature has shown that innovative firms (say, those investing in $R \& D$ or producing patents) are likely candidates for firms that must maintain lower leverage ratios. Their heavy reliance on equity markets requires that they keep their stock liquid. As such, innovative firms take actions that help improve their stock liquidity - either by reducing the information asymmetry surrounding the stock or by (indirectly) lowering the trading costs.

We find strong empirical evidence for these arguments in a large sample of public firms over 1990-2006. We find that innovative firms have: significantly lower stock illiquidity, higher turnovers, lower bid-ask spreads, and a lower probability of informed trading ("PIN"). This is an important finding because firms with informationally opaque assets are generally expected to have lower stock liquidity. This effect is weaker if the firm is less financially constrained and is able to access capital from other sources. Further, innovative firms are more likely to take deliberate steps that are known to improve stock liquidity, such as providing managerial guidance on future earnings, announcing stock splits, making seasoned equity offerings (SEOs), choosing more reputed underwriters, and generating trading interest in the stock such that options are more likely to be listed on their shares.

If the innovative firms do issue debt, it is more highly rated public debt; this is consistent with innovative firms returning to public capital markets, which helps improve informational transparency. Their private debt (i.e., bank loans) is less likely to have restrictive financial covenants; this reflects their lower leverage ratios and lower informational asymmetry. Given their reliance on equity markets, the role of monitoring the management rests with equity-holders. As such, we find that innovative firms have higher institutional ownership, higher likelihood of block holders, and more incentivized CEO compensation contracts. The preference of innovative firms for greater liquidity is reflected in a bigger impact on firm value due to an exogenous change in stock liquidity (say, following decimalization of stock prices). Finally, we find that increases in liquidity are also related with greater innovative activity in the subsequent years.

Overall, we find strong evidence of firms being able to influence stock liquidity by taking deliber- 
ate steps to dispel information asymmetry. This is especially true of firms that are most vulnerable to and most affected by informational asymmetries. 


\section{References}

Amihud, Yakov (2002), "Illiquidity and Stock Returns: Cross-section and time-series effects", Journal of Financial Markets, vol. 5(1), 31-56.

Amihud, Yakov, and Haim Mendelson (1988), "Liquidity and Asset Prices: Financial Management Implications", Financial Management, vol. 17(1), 5-15.

Amihud, Yakov, and Haim Mendelson (1991), "Liquidity, Asset Prices, and Financial Policy", Financial Analysts Journal, vol. 47(6), 56-66.

Balakrishnan, Karthik, Mary Billings, Bryan Kelly, and Alexander Ljungqvist (2011), "Shaping Liquidity: On the Causal Effects of Voluntary Disclosure", NYU working paper.

Beneish, Messod D., and Robert E. Whaley (1996), "An Anatomy of the 'S\&P Game': The Effects of Changing the Rules", Journal of Finance, vol. 51(5), 1909-1930.

Butler, Alexander W., Gustavo Grullon, and James P. Weston (2005), "Stock Market Liquidity and the Cost of Issuing Equity", Journal of Financial and Quantitative Analysis, vol. 40(2), 331-348.

Chava, Sudheer, Praveen Kumar, and Arthur Warga (2010), "Managerial Agency and Bond Covenants", Review of Financial Studies, vol. 23(3), 1120-1148.

Coller, Maribeth, and Teri L. Yohn (1997), "Management Forecasts and Information Asymmetry: An examination of bid-ask spreads", Journal of Accounting Research, vol. 35(2), 181-191.

Copeland, Thomas E. (1979), "Liquidity Changes Following Stock Splits", Journal of Finance, vol. $34(1), 115-141$.

Dennis, Patrick, and Deon Strickland (2003), "The Effect Of Stock Splits On Liquidity And Excess Returns: Evidence From Shareholder Ownership Composition", Journal of Financial Research, vol. 26(3), 355-370.

Diamond, Douglas W., and Robert E. Verrecchia (1991), "Disclosure, Liquidity, and the Cost of Capital", Journal of Finance, vol. 46(4), 1325-1359.

Easley, David, Søren Hvidkjær, and Maureen O'Hara (2002), "Is Information Risk a Determinant of Asset Returns?", Journal of Finance, vol. 57(5), pp. 2185-2221.

Easley, David, Nicholas M. Kiefer, Maureen O'Hara and Joseph B. Paperman (1996), "Liquidity, Information, and Infrequently Traded Stocks", Journal of Finance, vol. 51(4), 1405-1436 .

Easley, David, and Maureen O'Hara (2003), "Microstructure and Asset Pricing", in: George M. Constantinides, Milton Harris, and René M. Stulz, eds., Handbook of the Economics of Finance, vol. 1B, pp. 1021-1051, Amsterdam: Elsevier.

Easterbrook, Frank H. (1984), "Two Agency-Cost Explanations of Dividends", American Economic Review, vol. 74(4), 650-659.

Eckbo, B. Espen, Ronald W. Masulis, and Øyvind Norli (2000), "Seasoned Public Offerings: Resolution of the "new issues puzzle"', Journal of Financial Economics, vol. 56(2), 251-291.

Edmans, Alex, Xavier Gabaix and Augustin Landier (2009), "A Multiplicative Model of Optimal CEO Incentives in Market Equilibrium", Review of Financial Studies, vol. 22(12), 4881-4917. 
Edmans, Alex, and Gustavo Manso (2011), "Governance Through Trading and Intervention: A Theory of Multiple Blockholders", Review of Financial Studies, vol. 24(7), 2395-2428.

Ellis, Katrina, Roni Michaely and Maureen O'Hara (2000), "When the Underwriter Is the Market Maker: An Examination of Trading in the IPO Aftermarket", Journal of Finance, vol. 55(3), 1039-1074.

Fang, Vivian W., Thomas H. Noe, and Sheri Tice (2009), "Stock Market Liquidity and Firm Value", Journal of Financial Economics, vol. 94(1), 150-169.

Fang, Vivian W., Xuan Tian, and Sheri Tice (2012), "Does Stock Liquidity Enhance or Impede Firm Innovation?", working paper.

Gopalan, Radhakrishnan, Ohad Kadan, and Mikhail Pevzner (2011), "Asset Liquidity and Stock Liquidity", Journal of Financial and Quantitative Analysis, forthcoming.

Hall, Bronwyn, Adam Jaffe, and Manuel Trajtenberg (2001), "The NBER Patent Citations Data File: Lessons, Insights and Methodological Tools", NBER Working Paper 8498.

Harris, Lawrence, and Eitan Gurel (2003), "Price and Volume Effects Associated with Changes in the S\&P 500 List: New evidence for the existence of price pressures", Journal of Finance, vol. 41(4), 815-829.

Hegde, Shantaram P., and John B. McDermott (2003), "The Liquidity Effects of Revisions to the S\&P 500 Index: An empirical analysis", Journal of Financial Markets, vol. 6, 413459.

Holmström, Bengt, and Jean Tirole (1993), "Market Liquidity and Performance Monitoring", Journal of Political Economy, vol. 101(4), 678-709.

Kothare, Meeta (1997), "The Effects of Equity Issues on Ownership Structure and Stock Liquidity: A comparison of rights and public offerings", Journal of Financial Economics, vol. 43(1), 131-148.

Lakonishok, Josef, and Baruch Lev (1987), "Stock Splits and Stock Dividends: Why, Who, and When", Journal of Finance, vol. 42(4), 913-932.

Lin, Ji Chai, Ajai K. Singh, and Wen Yu (2009), "Stock Splits, Trading Continuity, and the Cost of Equity Capital", Journal of Financial Economics, vol. 93(3), 474-489.

Lynch, Anthony W., and Richard R. Mendenhall (2004), "New Evidence on Stock Price Effects Associated with Changes in the S\&P 500 Index", Journal of Business, vol. 70(3), 351-383.

Mayhew, Stewart, and Vassil Mihov (2004), "How Do Exchanges Select Stocks for Option Listing?", Journal of Finance, vol. 59(1), 447-471.

Merton, Robert C. (2007), "A Simple Model of Capital Market Equilibrium with Incomplete Information", Journal of Finance, vol. 42(3), 483-510.

Muscarella, Chris J., and Michael R. Vetsuypens (1996), "Stock Splits: Signaling or Liquidity? The case of ADR 'solo-splits"', Journal of Financial Economics, vol. 42(1), 3-26.

O'Hara, Maureen (2003), "Presidential Address: Liquidity and Price Discovery", Journal of Finance, vol. 58(4), pp. 1335-1354.

Odders-White, Elizabeth R., and Mark J. Ready (2006), "Credit Ratings and Stock Liquidity", Review of Financial Studies, vol. 19(1), 119-157. 
Roberts, Michael R., and Toni M. Whited (2011), "Endogeneity in Empirical Corporate Finance", Simon School Working Paper.

Shleifer, Andrei (1986), "Do Demand Curves for Stocks Slope Down?", Journal of Finance, vol. 41(3), 579-590.

Tirole, Jean (2002), The Theory of Industrial Organization, MIT Press: Cambridge, MA.

Titman, Sheridan, and Roberto Wessels (1988), "The Determinants of Capital Structure Choice", Journal of Finance, vol. 43(1), 1-19.

Waterson, Michael (1984), Economic Theory of The Industry, Cambridge University Press. 


\section{Appendix: Variable Definitions}

\section{Primary Dependent Variables}

- Illiquidity is defined as $\ln \left(\operatorname{AvgILLIQ} \times 10^{8}\right)$, where $A v g I L L I Q$ is an yearly average of illiquidity measured

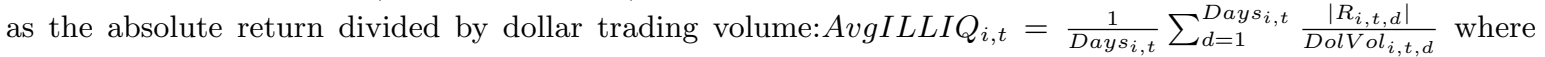
$D_{\text {Days }}, t$ is the number of valid observation days for stock $i$ in fiscal year $t$, and $R_{i, t, d}$ and $D_{o l V o l}, t, d$ are the return and dollar trading volume of stock $i$ on day $d$ in the fiscal year $t$.

- Negative Turnover $=-$ Turnover $_{i, t}=\frac{-1}{12} \sum_{m=1}^{12} \frac{\text { Vol }_{i, t, m}}{\text { Shrout }_{i, t, m}}$ where Vol $_{i, t, m}$ and Shrout $t_{i, t, m}$ are the trading volume in shares and number of shares outstanding for firm $i$ in month $m$ of fiscal year $t$. (We use "negative" turnover so that it measures illiquidity like the other dependent variables defined here.)

- $B i d-A s k \operatorname{Spread}_{i, t}=\frac{1}{\operatorname{Days}_{i, t}} \sum_{d=1}^{\operatorname{Days}_{i, t}} \frac{A s k_{i, t, d}-\operatorname{Bid}_{i, t, d}}{\left(A s k_{i, t, d}+\operatorname{Bid}_{i, t, d}\right) / 2}$ where $\operatorname{Days}_{i, t}$ is the number of observations for stock $i$ in fiscal year $t$, and $A s k_{i, t, d}$ and $B i d_{i, t, d}$ are the closing ask and bid prices of the stock $i$ on day $d$ of year $t$.

- PIN is the probability of informed trading proposed by Easley, Kiefer, O'Hara, and Paperman (1996). We obtain this variable directly from Søren Hvidkjær's website: http://sites.google.com/site/hvidkjaer/ data.

\section{Measures of Innovativeness}

- $R \mathscr{E} D$ is the ratio of the firm's R\&D expenditure to lagged assets.

- Log Patents is $\ln (1+$ number of patents granted $) / 100$.

- Log Citations is $\ln (1+$ number of citations on patents granted $) / 100$.

- Innovation Index $=\frac{0.3519 \times R \& D+0.6620 \times \log \text { Patents }+0.6618 \times \log \text { Citations }}{100}$ where each of the index components has first been winsorized at $1 \%$ and $99 \%$ level and standardized.

\section{Other Dependent Variables}

- Guidance is the logarithm of one plus the frequency of earnings guidance forecasts provided by the management in the fiscal year.

- Stock Splits is a binary variable that is equal to one if there is a stock split in the fiscal year, and it is zero otherwise.

- Listed Options is a binary variable that is equal to one if the firm has listed options available in the given fiscal year, and it is zero otherwise.

- SEO Dummy is a binary variable that is equal to one if the firm does a seasoned equity offering (SEO) in the given fiscal year, and it is zero otherwise.

- Reputed Underwriter is a binary variable that is equal to one if the firm hires a "reputable" underwriter for the SEO. Reputable underwriters are those that rank equal to or higher than eight in Prof. Jay Ritter's IPO Underwriter Reputation Rankings (1980-2009).

- Public Debt Dummy is a binary variable that is equal to one if the firm has a long-term S\&P credit rating, and it is zero otherwise.

- Credit Rating is an ordinal variable measuring the firm's long-term credit rating by S\&P. It is equal to 1 if the firm is rated $\mathrm{CCC}+$ or below; 2 if it is rated between $\mathrm{B}-$ to $\mathrm{B} ; 3$ if it is rated between $\mathrm{BB}-$ to $\mathrm{BB}+; 4$ if the rating $\mathrm{i}$ between $\mathrm{BBB}-$ to $\mathrm{BBB}+; 5$ if the rating is between $\mathrm{A}$ - to $\mathrm{A}+$; and 6 if the rating is $\mathrm{AA}$ - or higher.

- Covenant Dummy is a binary variable that is equal to one if there is a covenant in the loan borrowed by the firm in the given fiscal year, and it is zero otherwise. These data are from Dealscan.

- Number of Covenants counts the number of covenants in the bank loan issued in the given fiscal year. If there are multiple loans borrowed in the year, then we take an average of the number of covenants across all the loans weighted by the loan amount.

- Equity-Based Compensation is the sum of options and restricted stock granted to the CEO, divided by the CEO's total compensation.

- Wealth-Performance Sensitivity is the natural logarithm of scaled wealth-performance sensitivity following Edmans, Gabaix and Landier (2009).

- Institutional Ownership is the number of shares held by all the institutional investors listed in $13 F$, calculated as a ratio of the total number of the firm's shares outstanding. 
- Blockholder Dummy is a binary variable that is equal to one if there is at least one blockholder that has a minimum of $5 \%$ equity ownership in the firm, and it is zero otherwise.

\section{Firm Characteristics}

- Log Assets is the natural logarithm of total assets.

- Leverage is the sum of long term debt and debt in current liabilities divided by total assets.

- Cash is the cash and short term investments to lagged asset ratio.

- Tobin's $Q$ is the sum of total assets and the difference between market value and book value of total common equity, divided by total assets.

- $R O A$ is equal to earnings before extraordinary items to lagged asset ratio.

- Tangibility is the net total value of property, plant and equipment, divided by total assets.

- Firm's Age is the age of the firm in years.

- Return Volatility is the standard deviation of daily stock returns in the fiscal year.

- Stock Return is the annual stock returns in the fiscal year.

- Stock Price is the firm's fiscal year end closing price.

- Market Power is defined as sale minus cost of goods sold and selling, general and administrative expense, divided by sale.

- Market Power Dummy is a binary variable that is equal to 1 if the Market Power of the firm is higher than the sample median and 0 otherwise.

- High Ratings Dummy is a binary variable that is equal to 1 if the firm has S\&P credit rating equal to or higher than A- and 0 otherwise.

- NYSE Dummy is a binary variable that is equal to 1 if the firm is listed in the New York Stock Exchange and 0 otherwise.

- Dividend Dummy is a binary variable that is equal to 1 if the firm pays dividend to common or prefered stockholders in the fiscal year and 0 otherwise.

- Free Cash Flow is the sum of net cash flow from operating activities and net cash flow from investing activities, divided by total assets.

- Advertising is the advertising expense to lagged asset ratio.

- Investment is the capital expenditure divided by lagged net total value of property, plant and equipment.

- KZIndex is $3.139 \times$ Leverage $+0.283 \times$ Tobin's $^{\prime} Q-1.002 \times$ CashFlow $-39.368 \times$ Dividends $-1.315 \times$ Cash . CEO Characteristics

- $C E O$ age is the age of $\mathrm{CEO}$ in years.

- CEO Tenure measured in months for the CEO in the fiscal year.

- CEO Ownership is the CEO's stock ownership of the firm.

\section{Loan Characteristics}

- Log Loan Amount is the natural logarithm of loan amount borrowed in the fiscal year. If there are more than one loan borrowed in the year, the variable would be the sum of all the loans.

- Log Loan Maturity is the time to maturity of loan borrowed in the fiscal year. If there are more than one loan borrowed in the year, the variable would be an average of all the loans weighted by loan amount.

- Syndicate Dummy is a binary variable that is equal to 1 if at least one loan borrowed in the fiscal year is a syndicated loan.

\section{Innovation Measures used in Table 14}

- Patents is $\ln (1+$ number of evetually-granted patents applied $)$.

- Citations is $\ln (1+$ number of citations on patents applied $)$. 
Table 1: Summary Statistics. This table presents summary statistics of the variables used in our analyses.

\begin{tabular}{|c|c|c|c|c|c|}
\hline & Units & $\mathbf{N}$ & Mean & Median & Std. Dev. \\
\hline \multicolumn{6}{|c|}{ Primary Dependent Variables: } \\
\hline Illiquidity & & 82,447 & 2.639 & 2.693 & 3.370 \\
\hline Negative Turnover & & 82,460 & -0.118 & -0.073 & 0.138 \\
\hline Bid-Ask Spread & & 79,025 & 0.039 & 0.023 & 0.047 \\
\hline PIN & & 19,299 & 0.199 & 0.186 & 0.080 \\
\hline \multicolumn{6}{|l|}{ Measures of Innovativeness: } \\
\hline $\mathrm{R} \& \mathrm{D}$ & fraction & 82,460 & 0.047 & 0.000 & 0.085 \\
\hline Log Patents & logarithm & 82,460 & 0.004 & 0.000 & 0.008 \\
\hline Log Citations & logarithm & 82,460 & 0.007 & 0.000 & 0.016 \\
\hline Innovation Index & & 82,460 & 0.008 & -0.005 & 0.022 \\
\hline Advertising & & 82,460 & 0.009 & 0.000 & 0.021 \\
\hline \multicolumn{6}{|l|}{ Other Dependent Variables } \\
\hline Guidance & logarithm & 68,099 & 0.282 & 0.000 & 0.544 \\
\hline Stock Splits & $0 / 1$ & 82,460 & 0.072 & 0.000 & 0.259 \\
\hline SEO Dummy & $0 / 1$ & 82,460 & 0.058 & 0.000 & 0.233 \\
\hline Reputed Underwriter & $0 / 1$ & 4,748 & 0.732 & 1.000 & 0.443 \\
\hline Listed Options & $0 / 1$ & 58,019 & 0.369 & 0.000 & 0.483 \\
\hline Public Debt Dummy & $0 / 1$ & 82,460 & 0.225 & 0.000 & 0.418 \\
\hline Credit Rating & & 82,460 & 0.828 & 0.000 & 1.650 \\
\hline Covenant Dummy & $0 / 1$ & 15,356 & 0.527 & 1.000 & 0.499 \\
\hline Number of Covenants & & 15,356 & 1.140 & 0.909 & 1.310 \\
\hline Equity-Based Compensation & fraction & 18,133 & 0.381 & 0.383 & 0.296 \\
\hline Wealth-Performance Sensitivity & logarithm & 21,567 & 2.343 & 2.098 & 1.342 \\
\hline Institutional Ownership & fraction & 82,460 & 0.334 & 0.274 & 0.285 \\
\hline Blockholder Dummy & $0 / 1$ & 82,460 & 0.384 & 0.000 & 0.486 \\
\hline \multicolumn{6}{|c|}{ Firm-specific Control Variables: } \\
\hline Log Assets & logarithm & 82,460 & 5.235 & 5.041 & 2.225 \\
\hline Leverage & fraction & 82,460 & 0.230 & 0.188 & 0.221 \\
\hline Cash & fraction & 82,460 & 0.209 & 0.090 & 0.292 \\
\hline Tobin's Q & & 82,460 & 2.060 & 1.411 & 1.916 \\
\hline $\mathrm{ROA}$ & fraction & 82,460 & -0.038 & 0.028 & 0.251 \\
\hline Tangibility & fraction & 82,460 & 0.281 & 0.204 & 0.246 \\
\hline Firm's Age & year & 82,460 & 13.228 & 8.000 & 13.787 \\
\hline Return Volatility & & 82,460 & 0.042 & 0.035 & 0.027 \\
\hline Stock Return & $\%$ & 82,408 & 16.251 & 4.704 & 70.472 \\
\hline Stock Price & $\$$ & 82,176 & 16.801 & 10.625 & 17.718 \\
\hline Market Power & fraction & 66,566 & -0.045 & 0.094 & 0.781 \\
\hline High Rating Dummy & $0 / 1$ & 82,460 & 0.064 & 0.000 & 0.245 \\
\hline NYSE Dummy & $0 / 1$ & 82,460 & 0.295 & 0.000 & 0.456 \\
\hline Dividend Dummy & $0 / 1$ & 82,460 & 0.399 & 0.000 & 0.490 \\
\hline Free Cash Flow & fraction & 81,606 & -0.058 & -0.008 & 0.225 \\
\hline Investment & fraction & 79,434 & 0.383 & 0.221 & 0.508 \\
\hline KZIndex & & 81,494 & 0.544 & 0.604 & 1.549 \\
\hline \multicolumn{6}{|l|}{ Other Independent Variables: } \\
\hline CEO Age & year & 19,758 & 55.576 & 56.000 & 7.612 \\
\hline CEO Tenure & month & 20,213 & 79.509 & 50.000 & 90.121 \\
\hline CEO Ownership & $\%$ & 10,367 & 0.050 & 0.015 & 0.080 \\
\hline Log Loan Amount & logarithm & 15,356 & 4.815 & 5.011 & 1.738 \\
\hline Log Loan Maturity & logarithm & 14,174 & 3.602 & 3.767 & 0.719 \\
\hline Syndicate Dummy & $0 / 1$ & 15,356 & 0.693 & 1.000 & 0.461 \\
\hline
\end{tabular}


Table 2: Univariate Tests. In Panels A-E, we present univariate tests of Leverage and illiquidity measures (Illiquidity, Negative Turnover, Bid-Ask Spread, and PIN), comparing subsamples that have zero and positive value of REDD, Log Patents, Log Citations, and Innovation Index. In columns 2 and 3, we first report the mean, then the median in parentheses, and the number of observations in brackets.

Panel A: Univariate test of Leverage

\begin{tabular}{lccccc}
\hline & Dummy=0 & Dummy=1 & Mean (Difference) & T statistics & Wilcoxon Z \\
\hline \hline By R\&D Dummy & 0.279 & 0.169 & 0.110 & $73.20^{* * *}$ & $74.58^{* * *}$ \\
& $(0.257)$ & $(0.107)$ & & $74.58^{* * *}$ \\
By Patents Dummy & {$[46,419]$} & {$[36,041]$} & & $26.84^{* * *}$ \\
& 0.242 & 0.187 & 0.055 & $29.30^{* * *}$ & $26.84^{* * *}$ \\
& $(0.202)$ & $(0.148)$ & & $22.30^{* * *}$ \\
By Citations Dummy & {$[64,842]$} & {$[17,618]$} & & $25.78^{* * *}$ & $2.30^{* * *}$ \\
& 0.240 & 0.189 & 0.051 & & $74.34^{* * *}$ \\
By Innovation Index Dummy & $(0.199)$ & $(0.153)$ & & $70.86^{* * *}$ & $74.34^{* * *}$ \\
& {$[67,068]$} & {$[15,392]$} & 0.111 & & \\
\hline
\end{tabular}

Panel B: Univariate test of Illiquidity

\begin{tabular}{|c|c|c|c|c|c|}
\hline & Dummy $=0$ & Dummy $=1$ & Mean (Difference) & $\mathrm{T}$ statistics & Wilcoxon Z \\
\hline By R\&D Dummy & $\begin{array}{c}2.836 \\
(2.252) \\
{[46,408]}\end{array}$ & $\begin{array}{c}2.385 \\
(2.450) \\
{[36,039]}\end{array}$ & 0.450 & $19.08^{* * *}$ & $\begin{array}{l}18.33^{* * *} \\
18.33^{* * *}\end{array}$ \\
\hline By Patents Dummy & $\begin{array}{c}3.101 \\
(3.239) \\
{[64,830]}\end{array}$ & $\begin{array}{c}0.940 \\
(0.813) \\
{[17,617]}\end{array}$ & 2.161 & $78.24^{* * *}$ & $\begin{array}{l}73.80^{* * *} \\
73.80^{* * *}\end{array}$ \\
\hline By Citations Dummy & $\begin{array}{c}3.019 \\
(3.143) \\
{[67,056]}\end{array}$ & $\begin{array}{c}0.984 \\
(0.847) \\
{[15,391]}\end{array}$ & 2.035 & $69.51^{* * *}$ & $\begin{array}{l}65.94^{* * *} \\
65.94^{* * *}\end{array}$ \\
\hline By Innovation Index Dummy & $\begin{array}{c}3.022 \\
(3.175) \\
{[53,788]}\end{array}$ & $\begin{array}{c}1.921 \\
(1.940) \\
{[28,659]}\end{array}$ & 1.101 & $45.23^{* * *}$ & $\begin{array}{l}43.50^{* * *} \\
43.50^{* * *}\end{array}$ \\
\hline
\end{tabular}

Panel C: Univariate test of Negative Turnover

\begin{tabular}{|c|c|c|c|c|c|}
\hline & Dummy $=0$ & Dummy $=1$ & Mean (Difference) & T statistics & Wilcoxon Z \\
\hline By R\&D Dummy & $\begin{array}{c}-0.109 \\
(-0.060) \\
{[46,419]}\end{array}$ & $\begin{array}{c}-0.154 \\
(-0.094) \\
{[36,041]}\end{array}$ & 0.045 & $38.70^{* * *}$ & $\begin{array}{l}60.49^{* * *} \\
60.49 * * *\end{array}$ \\
\hline By Patents Dummy & $\begin{array}{c}-0.122 \\
(-0.067) \\
{[64,842]}\end{array}$ & $\begin{array}{c}-0.153 \\
(-0.099) \\
{[17,618]}\end{array}$ & 0.031 & $25.67^{* * *}$ & $\begin{array}{l}46.76^{* * *} \\
46.76^{* * *}\end{array}$ \\
\hline By Citations Dummy & $\begin{array}{c}-0.111 \\
(-0.069) \\
{[67,068]}\end{array}$ & $\begin{array}{c}-0.151 \\
(-0.096) \\
{[15,392]}\end{array}$ & 0.041 & $33.26^{* * *}$ & $\begin{array}{l}39.34^{* * *} \\
39.34^{* * *}\end{array}$ \\
\hline By Innovation Index Dummy & $\begin{array}{c}-0.098 \\
(-0.061) \\
{[53,800]}\end{array}$ & $\begin{array}{l}-0.156 \\
(-0.103) \\
{[28,660]}\end{array}$ & 0.058 & $59.12^{* * *}$ & $\begin{array}{l}69.91^{* * *} \\
69.91^{* * *}\end{array}$ \\
\hline
\end{tabular}


Panel D: Univariate test of Bid-Ask Spread

\begin{tabular}{lccccc}
\hline & Dummy=0 & Dummy=1 & Mean (Difference) & T statistics & Wilcoxon Z \\
\hline \hline By R\&D Dummy & 0.043 & 0.035 & 0.008 & $23.75^{* * *}$ & $21.64^{* * *}$ \\
& $(0.025)$ & $(0.021)$ & & $21.64^{* * *}$ \\
By Patents Dummy & {$[44,225]$} & {$[34,800]$} & & $61.36^{* * *}$ \\
& 0.044 & 0.023 & 0.021 & $51.70^{* * *}$ & $61.36^{* * *}$ \\
& $(0.027)$ & $(0.013)$ & & $44.73^{* * *}$ \\
By Citations Dummy & {$[62,064]$} & {$[16,961]$} & & $41.92^{* * *}$ & $44.73^{* * *}$ \\
& 0.043 & 0.025 & 0.018 & $36.50^{* * *}$ & $36.89^{* * *}$ \\
By Innovation Index Dummy & $(0.026)$ & $(0.015)$ & & $36.89^{* * *}$ \\
& {$[64,284]$} & {$[14,741]$} & 0.013 & & 3 \\
\hline
\end{tabular}

Panel E: Univariate test of $P I N$

\begin{tabular}{lccccc}
\hline & Dummy=0 & Dummy=1 & Mean (Difference) & T statistics & Wilcoxon Z \\
\hline \hline By R\&D Dummy & 0.202 & 0.194 & 0.008 & $6.20^{* * *}$ & $6.00^{* * *}$ \\
& $(0.188)$ & $(0.182)$ & & $6.00^{* * *}$ \\
By Patents Dummy & {$[12,547]$} & {$[6,752]$} & & $28.035^{* * *}$ & $28.93^{* * *}$ \\
& 0.209 & 0.172 & 0.036 & $28.93^{* * *}$ \\
By Citations Dummy & $(0.196)$ & $(0.159)$ & & $29.07^{* * *}$ & $29.22^{* * *}$ \\
& {$[14,310]$} & {$[4,989]$} & & $29.22^{* * *}$ \\
By Innovation Index Dummy & 0.208 & 0.172 & 0.037 & $22.82^{* * *}$ & $23.17^{* * *}$ \\
& $(0.196)$ & $(0.159)$ & & $23.17^{* * *}$ \\
\hline
\end{tabular}


Table 3: Stock Liquidity of Innovative Firms. In this table, we show that innovative firms tend to have lower stock $i$ lliquidity. We present estimates from regressions with firm random-effects, where the dependent variable is a measure of the firm's stock illiquidity and the independent variable of interest is a measure of innovation. We start with the dependent variable Illiquidity in Panel A and then alternatively use Negative Turnover, Bid-Ask Spread, and PIN in Panels B, C, and D, respectively. All these dependent variables are measured in year $t+1$ while the independent variables are measured in year $t$. The following firm characteristics are also included in the regressions: Log Assets, Leverage, Cash, Tobin's Q, NYSE Dummy, ROA, Tangibility, Firm's Age, and Return Volatility. All the variables are defined in the Appendix. Year and industry dummies are also included.

Panel A: Dependent Variable is Illiquidity

\begin{tabular}{|c|c|c|c|c|}
\hline INDEPENDENT VARIABLES & $(1)$ & $(2)$ & $(3)$ & $(4)$ \\
\hline $\mathrm{R} \& \mathrm{D}$ & $\begin{array}{c}-1.941 * * * \\
{[-12.38]}\end{array}$ & & & \\
\hline Log Patent & & $\begin{array}{c}-13.607 * * * \\
{[-10.52]}\end{array}$ & & \\
\hline Log Citation & & & $\begin{array}{c}-4.893^{* * *} \\
{[-9.92]}\end{array}$ & \\
\hline Innovation Index & & & & $\begin{array}{c}-6.520^{* * *} \\
{[-13.62]}\end{array}$ \\
\hline Log Assets & $\begin{array}{c}-1.119 * * * \\
{[-108.68]}\end{array}$ & $\begin{array}{c}-1.104^{* * *} \\
{[-106.56]}\end{array}$ & $\begin{array}{c}-1.107 * * * \\
{[-107.37]}\end{array}$ & $\begin{array}{r}-1.103^{* * *} \\
{[-106.96]}\end{array}$ \\
\hline Leverage & $\begin{array}{c}1.500^{* * *} \\
{[29.63]}\end{array}$ & $\begin{array}{c}1.521^{* * *} \\
{[30.15]}\end{array}$ & $\begin{array}{c}1.516^{* * *} \\
{[29.99]}\end{array}$ & $\begin{array}{c}1.507^{* * *} \\
{[29.85]}\end{array}$ \\
\hline Cash & $\begin{array}{c}-0.531 * * * \\
{[-19.23]}\end{array}$ & $\begin{array}{c}-0.613^{* * *} \\
{[-22.91]}\end{array}$ & $\begin{array}{c}-0.609 * * * \\
{[-22.77]}\end{array}$ & $\begin{array}{c}-0.595 * * * \\
{[-22.26]}\end{array}$ \\
\hline Tobin's Q & $\begin{array}{c}-0.416^{* * *} \\
{[-73.57]}\end{array}$ & $\begin{array}{c}-0.423^{* * *} \\
{[-75.43]}\end{array}$ & $\begin{array}{c}-0.423 * * * \\
{[-75.28]}\end{array}$ & $\begin{array}{c}-0.421^{* * *} \\
{[-74.89]}\end{array}$ \\
\hline NYSE Dummy & $\begin{array}{c}-0.810^{* * *} \\
{[-17.65]}\end{array}$ & $\begin{array}{c}-0.790 * * * \\
{[-17.29]}\end{array}$ & $\begin{array}{c}-0.793^{* * *} \\
{[-17.35]}\end{array}$ & $\begin{array}{c}-0.793 * * * \\
{[-17.39]}\end{array}$ \\
\hline ROA & $\begin{array}{c}-1.117^{* * *} * \\
{[-28.84]}\end{array}$ & $\begin{array}{c}-1.020 * * * \\
{[-27.15]}\end{array}$ & $\begin{array}{c}-1.018^{* * *} \\
{[-27.11]}\end{array}$ & $\begin{array}{c}-1.049 * * * \\
{[-27.90]}\end{array}$ \\
\hline Tangibility & $\begin{array}{c}0.211^{* * *} \\
{[3.01]}\end{array}$ & $\begin{array}{c}0.179^{* *} \\
{[2.56]}\end{array}$ & $\begin{array}{c}0.187^{* * *} \\
{[2.67]}\end{array}$ & $\begin{array}{c}0.186^{* * *} \\
{[2.67]}\end{array}$ \\
\hline Firm's Age & $\begin{array}{c}-0.003^{*} \\
{[-1.73]}\end{array}$ & $\begin{array}{l}-0.002 \\
{[-0.93]}\end{array}$ & $\begin{array}{l}-0.002 \\
{[-1.17]}\end{array}$ & $\begin{array}{l}-0.002 \\
{[-0.95]}\end{array}$ \\
\hline Return Volatility & $\begin{array}{c}11.321^{* * *} \\
{[27.15]}\end{array}$ & $\begin{array}{c}11.472^{* * * *} \\
{[27.52]}\end{array}$ & $\begin{array}{c}11.492^{* * *} \\
{[27.60]}\end{array}$ & $\begin{array}{c}11.474^{* * *} \\
{[27.56]}\end{array}$ \\
\hline Intercept & $\begin{array}{c}8.203^{* * *} \\
{[85.59]}\end{array}$ & $\begin{array}{c}8.107^{* * *} \\
{[84.48]}\end{array}$ & $\begin{array}{c}8.088^{* * *} \\
{[84.12]}\end{array}$ & $\begin{array}{c}8.057^{* * *} \\
{[83.91]}\end{array}$ \\
\hline Observations & 81,604 & 81,604 & 81,604 & 81,604 \\
\hline R-squared & $76.1 \%$ & $76.2 \%$ & $76.1 \%$ & $76.3 \%$ \\
\hline Firm Random-effects & Yes & Yes & Yes & Yes \\
\hline Industry Dummies & Yes & Yes & Yes & Yes \\
\hline Year Dummies & Yes & Yes & Yes & Yes \\
\hline
\end{tabular}

$t$-statistics using robust, firm-clustered standard errors are in brackets

*** $\mathrm{p}<0.01, * * \mathrm{p}<0.05, * \mathrm{p}<0.1$ 
Panel B: Dependent Variable is Negative Turnover

\begin{tabular}{|c|c|c|c|c|}
\hline INDEPENDENT VARIABLES & $(1)$ & $(2)$ & $(3)$ & $(4)$ \\
\hline $\mathrm{R} \& \mathrm{D}$ & $\begin{array}{c}-0.127 * * * \\
{[-8.11]}\end{array}$ & & & \\
\hline Log Patent & & $\begin{array}{c}-0.537^{* * *} \\
{[-4.38]}\end{array}$ & & \\
\hline Log Citation & & & $\begin{array}{c}-0.236^{* * *} \\
{[-5.07]}\end{array}$ & \\
\hline Innovation Index & & & & $\begin{array}{c}-0.317 * * * \\
{[-7.15]}\end{array}$ \\
\hline Firm Control Variables & Yes & Yes & Yes & Yes \\
\hline Observations & 81,665 & 81,665 & 81,665 & 81,665 \\
\hline R-squared & $23.9 \%$ & $23.7 \%$ & $23.7 \%$ & $23.9 \%$ \\
\hline Firm Random-effects & Yes & Yes & Yes & Yes \\
\hline Industry \& Year Dummies & Yes & Yes & Yes & Yes \\
\hline
\end{tabular}

Panel C: Dependent Variable is Bid-Ask Spread

\begin{tabular}{lcccc}
\hline INDEPENDENT VARIABLES & $(1)$ & $(2)$ & $(3)$ & $(4)$ \\
\hline R\&D & & & & \\
& $-0.041^{* * *}$ & & & \\
Log Patent & {$[-11.56]$} & & & \\
& & $-0.058^{* *}$ & & \\
Log Citation & & {$[-2.39]$} & & $-0.093^{* * *}$ \\
& & & {$[-9.64]$} & \\
Innovation Index & & & & $-0.091^{* * *}$ \\
& & & & {$[-9.73]$} \\
Firm Control Variables & Yes & Yes & Yes & Yes \\
& & & & \\
Observations & 81,005 & 81,005 & 81,005 & 81,005 \\
R-squared & $51.8 \%$ & $51.5 \%$ & $51.5 \%$ & $51.5 \%$ \\
Firm Random-effects & Yes & Yes & Yes & Yes \\
Industry \& Year Dummies & Yes & Yes & Yes & Yes \\
\hline
\end{tabular}

Panel D: Dependent Variable is PIN

\begin{tabular}{|c|c|c|c|c|}
\hline INDEPENDENT VARIABLES & $(1)$ & $(2)$ & $(3)$ & $(4)$ \\
\hline $\mathrm{R} \& \mathrm{D}$ & $\begin{array}{c}-0.083^{* * *} \\
{[-4.67]}\end{array}$ & & & \\
\hline Log Patent & & $\begin{array}{l}0.042 \\
{[0.52]}\end{array}$ & & \\
\hline Log Citation & & & $\begin{array}{l}-0.009 \\
{[-0.25]}\end{array}$ & \\
\hline Innovation Index & & & & $\begin{array}{l}-0.019 \\
{[-0.61]}\end{array}$ \\
\hline Firm Control Variables & Yes & Yes & Yes & Yes \\
\hline Observations & 17,877 & 17,877 & 17,877 & 17,877 \\
\hline R-squared & $51.0 \%$ & $50.9 \%$ & $50.9 \%$ & $50.9 \%$ \\
\hline Firm Random-effects & Yes & Yes & Yes & Yes \\
\hline Industry \& Year Dummies & Yes & Yes & Yes & Yes \\
\hline
\end{tabular}


Table 4: Robustness Checks. In this table, we show that the association between innovativeness and stock illiquidity is robust: to the inclusion of firm fixed effects, to the inclusion of industry $\times$ year fixed effects, and in various industry subsamples. We present estimates using Illiquidity as the dependent variable and the independent variable of interest is a measure of innovation. In Panel A, we control for firm fixed effects in addition to year fixed effects. In Panel B, we control for industry $\times$ year fixed effects. In Panel C, we estimate equation (1) for different industry subsamples based on SIC codes: agriculture, forestry and fishing (Column 1, SIC between 100 and 999), mining (Column 2, SIC between 1000 and 1499), construction (Column 3, SIC between 1500 and 1799), manufacturing (Column 4, SIC between 2000 and 3999), transportation, communication, electric, gas and sanitary services (Column 5, SIC between 4000 and 4999), wholesale trade (Column 6, SIC between 5000 and 5199), retail trade (Column 7, SIC between 5200 and 5999), finance, insurance, and real estate (Column 8, SIC between 6000 and 6799), services (Column 9, SIC between 7000 and 8999). The following firm characteristics are also included in the regressions: Log Assets, Leverage, Cash, Tobin's Q, ROA, Tangibility, Firm's Age, and Return Volatility; their coefficients are not reported in Panels A and B for conserving space. All the variables are defined in the Appendix.

Panel A: Controlling for Firm Fixed Effects

\begin{tabular}{|c|c|c|c|c|}
\hline \multirow[b]{2}{*}{ INDEPENDENT VARIABLES } & \multicolumn{4}{|c|}{ Dependent Variable is Illiquidity } \\
\hline & $(1)$ & $(2)$ & $(3)$ & $(4)$ \\
\hline $\mathrm{R} \& \mathrm{D}$ & $\begin{array}{c}-1.203^{* * *} \\
{[-6.39]}\end{array}$ & & & \\
\hline Log Patent & & $\begin{array}{r}-4.125^{* *} \\
{[-2.79]}\end{array}$ & & \\
\hline Log Citation & & & $\begin{array}{r}-1.425^{* *} \\
{[-2.70]}\end{array}$ & \\
\hline Innovation Index & & & & $\begin{array}{c}-2.478^{* * *} \\
{[-4.56]}\end{array}$ \\
\hline Firm Control Variables & Yes & Yes & Yes & Yes \\
\hline Observations & 81,604 & 81,604 & 81,604 & 81,604 \\
\hline R-squared & $74.0 \%$ & $73.7 \%$ & $73.7 \%$ & $73.9 \%$ \\
\hline Firm Fixed-effects & Yes & Yes & Yes & Yes \\
\hline Year Dummies & Yes & Yes & Yes & Yes \\
\hline
\end{tabular}

$t$-statistics using robust, firm-clustered standard errors are in brackets

$* * * \mathrm{p}<0.01,{ }^{* *} \mathrm{p}<0.05,{ }^{*} \mathrm{p}<0.1$

Panel B: Controlling for Industry $\times$ Year Fixed Effects

\begin{tabular}{|c|c|c|c|c|}
\hline \multirow[b]{2}{*}{ INDEPENDENT VARIABLES } & \multicolumn{4}{|c|}{ Dependent Variable is Illiquidity } \\
\hline & $(1)$ & $(2)$ & $(3)$ & $(4)$ \\
\hline $\mathrm{R} \& \mathrm{D}$ & $\begin{array}{c}-1.899 * * * \\
{[-12.32]}\end{array}$ & & & \\
\hline Log Patent & & $\begin{array}{c}-15.091 * * * \\
{[-11.47]}\end{array}$ & & \\
\hline Log Citation & & & $\begin{array}{c}-5.060 * * * \\
{[-10.18]}\end{array}$ & \\
\hline Innovation Index & & & & $\begin{array}{c}-6.798^{* * *} \\
{[-14.12]}\end{array}$ \\
\hline Firm Control Variables & Yes & Yes & Yes & Yes \\
\hline Observations & 81,604 & 81,604 & 81,604 & 81,604 \\
\hline R-squared & $76.6 \%$ & $76.7 \%$ & $76.6 \%$ & $76.9 \%$ \\
\hline Firm Random-effects & Yes & Yes & Yes & Yes \\
\hline Year $\times$ Industry Dummies & Yes & Yes & Yes & Yes \\
\hline
\end{tabular}

$t$-statistics using robust, firm-clustered standard errors are in brackets

*** $\mathrm{p}<0.01,{ }^{*} * \mathrm{p}<0.05,{ }^{*} \mathrm{p}<0.1$ 


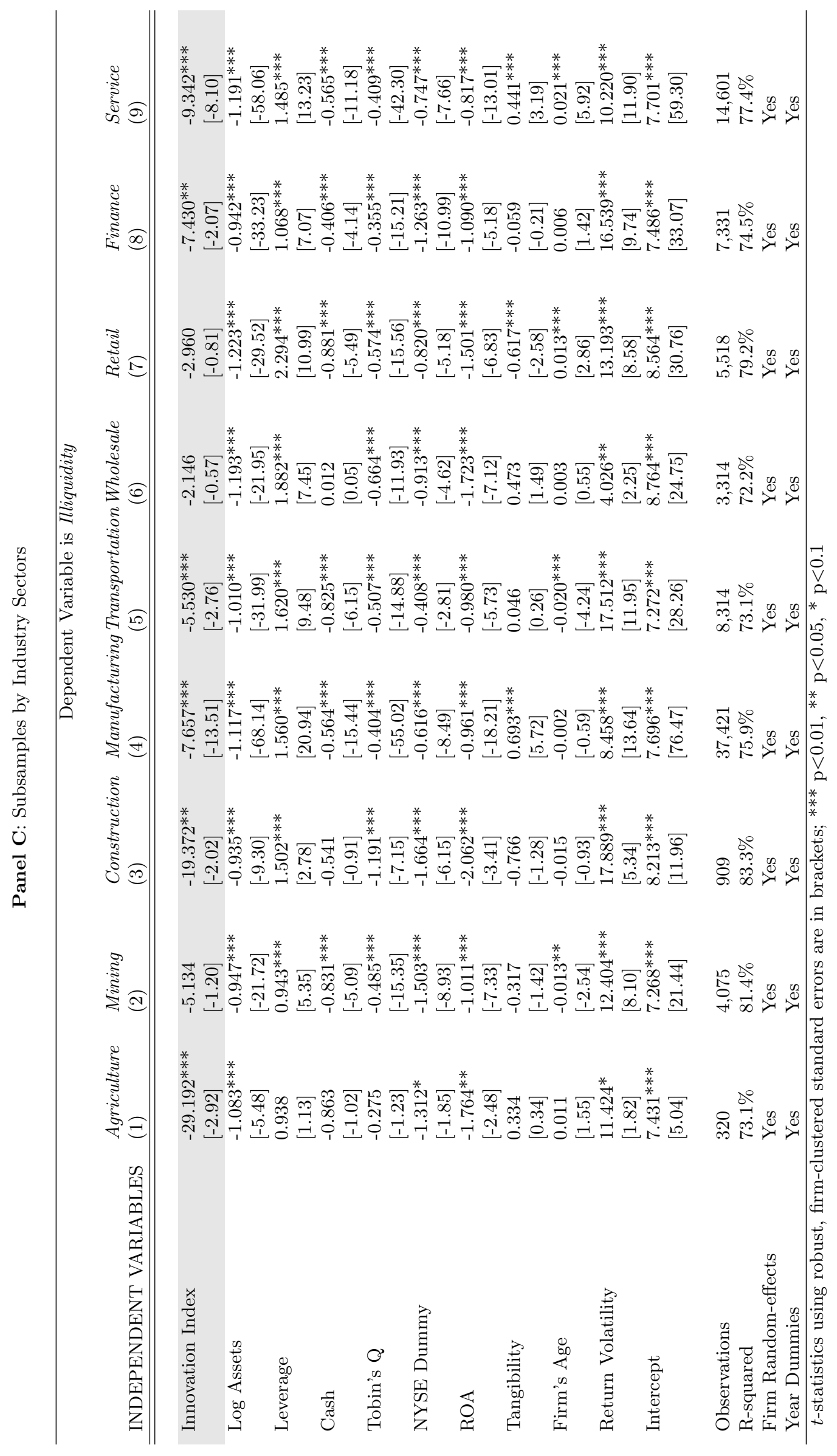


Table 5: Stock Liquidity of Innovative Firms Conditional on Access to Public Debt, Market Power, and Dividend Policy. In this table, we show that the relationship between innovation and the stock liquidity is weaker when the firm has access to alternative sources of capital or is not financially constrained (i.e., pays dividend). We present estimates from regressions with firm random-effects, where the dependent variables are the different measures of the firm's stock illiquidity and the independent variables of interest is the innovation index and its interaction with Public Debt Dummy (Panel A), High Ratings Dummy (Panel B), Market Power Dummy (Panel C), and Dividend Dummy (Panel D). The following firm characteristics are also included in the regressions: Log Assets, Leverage, Cash, Tobin'sQ, NYSE Dummy, ROA, Tangibility, Firm's Age and Return Volatility. The coefficients of these control variables are not reported for brevity. Year and industry dummies are also included. All the variables are defined in the Appendix.

Panel A: Access to Public Debt Market

\begin{tabular}{lcccc}
\hline & \multicolumn{4}{c}{ Dependent Variable is: } \\
& Illiquidity & Negative Turnover & Bid-Ask Spread & PIN \\
INDEPENDENT VARIABLES & $(1)$ & $(2)$ & $(3)$ & $(4)$ \\
\hline \hline & & & & \\
Index $\times$ Public Debt Dummy & 0.689 & $0.215^{* * *}$ & $0.050^{* * *}$ & $0.129^{* * *}$ \\
& {$[0.84]$} & {$[2.67]$} & {$[3.29]$} & {$[2.95]$} \\
Innovation Index & $-6.713^{* * *}$ & $-0.376^{* * *}$ & $-0.106^{* * *}$ & $-0.088^{* *}$ \\
& {$[-12.77]$} & {$[-7.50]$} & {$[-10.01]$} & {$[-2.05]$} \\
Public Debt Dummy & $-0.178^{* * *}$ & $-0.007^{* * *}$ & $0.006^{* * *}$ & $-0.006^{* * *}$ \\
& {$[-5.50]$} & {$[-3.15]$} & {$[10.21]$} & {$[-3.55]$} \\
Firm Control Variables & Yes & Yes & Yes & Yes \\
Observations & & & 81,005 & 17,877 \\
R-squared & 81,604 & 81,665 & $51.7 \%$ & $51.1 \%$ \\
Firm Random-effects & $76.4 \%$ & $24.0 \%$ & Yes & Yes \\
Industry Dummies & Yes & Yes & Yes & Yes \\
Year Dummies & Yes & Yes & Yes & Yes \\
\hline
\end{tabular}

$t$-statistics using robust, firm-clustered standard errors are in brackets

$* * * \mathrm{p}<0.01, * * \mathrm{p}<0.05, * \mathrm{p}<0.1$

Panel B: Credit Ratings are High

\begin{tabular}{lcccc}
\hline & \multicolumn{4}{c}{ Dependent Variable is: } \\
& Illiquidity & Negative Turnover & Bid-Ask Spread & PIN \\
INDEPENDENT VARIABLES & $(1)$ & $(2)$ & $(3)$ & $(4)$ \\
\hline \hline & & & & \\
Index $\times$ High Rating Dummy & $3.245^{* * *}$ & $0.534^{* * *}$ & $0.058^{* * *}$ & $0.117^{* * *}$ \\
& {$[3.05]$} & {$[6.14]$} & {$[2.65]$} & {$[2.74]$} \\
Innovation Index & $-6.838^{* * *}$ & $-0.385^{* * *}$ & $-0.098^{* * *}$ & -0.042 \\
& {$[-14.06]$} & {$[-8.41]$} & {$[-10.29]$} & {$[-1.22]$} \\
High Rating Dummy & -0.029 & $0.020^{* * *}$ & $0.002^{* * *}$ & $-0.006^{* * *}$ \\
& {$[-0.72]$} & {$[6.93]$} & {$[3.57]$} & {$[-3.31]$} \\
Firm Control Variables & Yes & Yes & Yes & Yes \\
Observations & & & & 17,005 \\
R-squared & 81,604 & 81,665 & $51.7 \%$ & $51.0 \%$ \\
Firm Random-effects & $76.3 \%$ & $24.7 \%$ & Yes & Yes \\
Industry Dummies & Yes & Yes & Yes & Yes \\
Year Dummies & Yes & Yes & Yes & Yes \\
\hline
\end{tabular}

$t$-statistics using robust, firm-clustered standard errors are in brackets

$* * * \mathrm{p}<0.01, * * \mathrm{p}<0.05, * \mathrm{p}<0.1$ 
Panel C: Access to More Trade Credit

\begin{tabular}{lcccc}
\hline & \multicolumn{4}{c}{ Dependent Variable is: } \\
& Iliquidity & Negative Turnover & Bid-Ask Spread & PIN \\
INDEPENDENT VARIABLES & $(1)$ & $(2)$ & $(3)$ & $(4)$ \\
\hline \hline & & & & \\
Index $\times$ Market Power Dummy & $5.079^{* * *}$ & -0.048 & $0.178^{* * *}$ & $0.112^{* * *}$ \\
& {$[8.64]$} & {$[-0.79]$} & {$[14.68]$} & {$[2.60]$} \\
Innovation Index & $-8.530^{* * *}$ & $-0.254^{* * *}$ & $-0.170^{* * *}$ & -0.068 \\
& {$[-14.20]$} & {$[-4.58]$} & {$[-13.93]$} & {$[-1.45]$} \\
Market Power Dummy & $-0.520^{* * *}$ & $-0.017^{* * *}$ & $-0.005^{* * *}$ & $-0.009^{* * *}$ \\
& {$[-26.14]$} & {$[-10.14]$} & {$[-10.47]$} & {$[-5.73]$} \\
Firm Control Variables & Yes & Yes & Yes & Yes \\
Observations & & & 65,356 & 14,144 \\
R-squared & 65,838 & 65,880 & $51.6 \%$ & $50.6 \%$ \\
Firm Random-effects & $77.3 \%$ & $24.9 \%$ & Yes & Yes \\
Industry Dummies & Yes & Yes & Yes & Yes \\
Year Dummies & Yes & Yes & Yes & Yes \\
\hline
\end{tabular}

$t$-statistics using robust, firm-clustered standard errors are in brackets

$* * * \mathrm{p}<0.01, * * \mathrm{p}<0.05,{ }^{*} \mathrm{p}<0.1$

Panel D: Financially Unconstrained

\begin{tabular}{|c|c|c|c|c|}
\hline \multirow[b]{2}{*}{ INDEPENDENT VARIABLES } & \multicolumn{4}{|c|}{ Dependent Variable is: } \\
\hline & $\begin{array}{l}\text { Illiquidity } \\
(1)\end{array}$ & $\begin{array}{c}\text { Negative Turnover } \\
(2)\end{array}$ & $\begin{array}{c}\text { Bid-Ask Spread } \\
(3)\end{array}$ & $\begin{array}{c}P I N \\
(4) \\
\end{array}$ \\
\hline Index $\times$ Dividend Dummy & $\begin{array}{c}1.455^{* *} \\
{[2.01]}\end{array}$ & $\begin{array}{c}0.306^{* * *} \\
{[4.32]}\end{array}$ & $\begin{array}{c}0.048^{* * *} \\
{[3.24]}\end{array}$ & $\begin{array}{l}0.083 \\
{[1.64]}\end{array}$ \\
\hline Innovation Index & $\begin{array}{c}-7.080^{* * *} \\
{[-12.72]}\end{array}$ & $\begin{array}{c}-0.432^{* * *} \\
{[-7.77]}\end{array}$ & $\begin{array}{c}-0.110^{* * *} \\
{[-9.96]}\end{array}$ & $\begin{array}{l}-0.076 \\
{[-1.56]}\end{array}$ \\
\hline Dividend Dummy & $\begin{array}{c}0.050^{* *} \\
{[2.18]}\end{array}$ & $\begin{array}{c}0.006^{* * *} \\
{[3.87]}\end{array}$ & $\begin{array}{c}-0.001^{* *} \\
{[-2.37]}\end{array}$ & $\begin{array}{l}-0.002 \\
{[-1.22]}\end{array}$ \\
\hline Firm Control Variables & Yes & Yes & Yes & Yes \\
\hline Observations & 81,604 & 81,665 & 81,005 & 17,877 \\
\hline R-squared & $76.4 \%$ & $24.4 \%$ & $51.6 \%$ & $51.0 \%$ \\
\hline Firm Random-effects & Yes & Yes & Yes & Yes \\
\hline Industry Dummies & Yes & Yes & Yes & Yes \\
\hline Year Dummies & Yes & Yes & Yes & Yes \\
\hline
\end{tabular}

$t$-statistics using robust, firm-clustered standard errors are in brackets

$* * * \mathrm{p}<0.01, * * \mathrm{p}<0.05, * \mathrm{p}<0.1$ 
Table 6: Actions of Innovative Firms to Improve Stock Liquidity. In this table, we show that innovative firms take deliberate actions to improve or maintain a high stock liquidity. Panel A presents results from a randomeffects model with Guidance as the dependent variable. In the remaining Panels B-E, we use a Probit model with firm random-effects where the discrete dependent variables are Stock Splits, SEO Dummy, Reputed Underwriter, and Listed Options, respectively. The dependent variables are measured in year $t+1$ while the independent variables are measured in year $t$. The independent variables of interest are the four proxies for innovation: R\&D, Log Patents, Log Citations, and Innovation Index. The following firm characteristics are also included in the regressions: Log Assets, Leverage, Cash, Tobin's Q, NYSE Dummy, ROA, Tangibility, Firm's Age, Return Volatility, and Stock Return. In Panel B, we also include Stock Price. Coefficients of the control variables are not reported for brevity. All the variables are defined in the Appendix. Year and industry dummies are also included.

Panel A: Dependent Variable is Guidance

\begin{tabular}{|c|c|c|c|c|}
\hline INDEPENDENT VARIABLES & $(1)$ & $(2)$ & $(3)$ & $(4)$ \\
\hline $\mathrm{R} \& \mathrm{D}$ & $\begin{array}{c}0.143^{* * *} \\
{[3.41]}\end{array}$ & & & \\
\hline Log Patent & & $\begin{array}{c}4.379^{* * *} \\
{[7.83]}\end{array}$ & & \\
\hline Log Citation & & & $\begin{array}{c}1.029 * * * \\
{[5.24]}\end{array}$ & \\
\hline Innovation Index & & & & $\begin{array}{c}1.382^{* * *} \\
{[5.24]}\end{array}$ \\
\hline Firm Control Variables & Yes & Yes & Yes & Yes \\
\hline Observations & 72,467 & 72,467 & 72,467 & 72,467 \\
\hline R-squared & $21.2 \%$ & $21.9 \%$ & $21.5 \%$ & $21.8 \%$ \\
\hline Firm Random-effects & Yes & Yes & Yes & Yes \\
\hline Industry \& Year Dummies & Yes & Yes & Yes & Yes \\
\hline
\end{tabular}


Panel B: Dependent Variable is Stock Splits

\begin{tabular}{|c|c|c|c|c|}
\hline INDEPENDENT VARIABLES & $(1)$ & $(2)$ & $(3)$ & $(4)$ \\
\hline Stock Price $\times$ R\&D Dummy & $\begin{array}{l}0.001 \\
{[1.23]}\end{array}$ & & & \\
\hline Stock Price $\times$ Patent Dummy & & $\begin{array}{c}0.002^{* *} \\
{[2.13]}\end{array}$ & & \\
\hline Stock Price $\times$ Citation Dummy & & & $\begin{array}{c}0.003^{* * *} \\
{[3.62]}\end{array}$ & \\
\hline Stock Price $\times$ Index Dummy & & & & $\begin{array}{c}0.003^{* * *} \\
{[3.39]}\end{array}$ \\
\hline Stock Price & $\begin{array}{c}0.039^{* * *} \\
{[44.55]}\end{array}$ & $\begin{array}{c}0.039^{* * *} \\
{[46.80]}\end{array}$ & $\begin{array}{c}0.039^{* * *} \\
{[47.07]}\end{array}$ & $\begin{array}{c}0.038^{* * *} \\
{[45.16]}\end{array}$ \\
\hline R\&D Dummy & $\begin{array}{c}-0.055^{*} \\
{[-1.70]}\end{array}$ & & & \\
\hline Log Patent Dummy & & $\begin{array}{c}-0.081^{* *} \\
{[-2.29]}\end{array}$ & & \\
\hline Log Citation Dummy & & & $\begin{array}{c}-0.125^{* * *} \\
{[-3.40]}\end{array}$ & \\
\hline Index Dummy & & & & $\begin{array}{c}-0.129 * * * \\
{[-4.14]}\end{array}$ \\
\hline Firm Control Variables & Yes & Yes & Yes & Yes \\
\hline Observations & 81,525 & 81,525 & 81,525 & 81,525 \\
\hline Pseudo R-squared & $1.6 \%$ & $1.7 \%$ & $1.7 \%$ & $1.6 \%$ \\
\hline Firm Random-effects & Yes & Yes & Yes & Yes \\
\hline Industry \& Year Dummies & Yes & Yes & Yes & Yes \\
\hline
\end{tabular}

Panel C: Dependent Variable is SEO Dummy

\begin{tabular}{|c|c|c|c|c|}
\hline INDEPENDENT VARIABLES & $(1)$ & $(2)$ & $(3)$ & $(4)$ \\
\hline $\mathrm{R} \& \mathrm{D}$ & $\begin{array}{c}1.147^{* * *} \\
{[6.70]}\end{array}$ & & & \\
\hline Log Patent & & $\begin{array}{c}3.426^{* *} \\
{[2.37]}\end{array}$ & & \\
\hline Log Citation & & & $\begin{array}{c}2.245^{* * *} \\
{[3.35]}\end{array}$ & \\
\hline Innovation Index & & & & $\begin{array}{c}2.411^{* * *} \\
{[4.37]}\end{array}$ \\
\hline Firm Control Variables & Yes & Yes & Yes & Yes \\
\hline Observations & 81,795 & 81,795 & 81,795 & 81,795 \\
\hline Pseudo R-squared & $1.2 \%$ & $1.2 \%$ & $1.2 \%$ & $1.2 \%$ \\
\hline Firm Random-effects & Yes & Yes & Yes & Yes \\
\hline Industry \& Year Dummies & Yes & Yes & Yes & Yes \\
\hline
\end{tabular}


Panel D: Dependent Variable is Reputed Underwriter

\begin{tabular}{|c|c|c|c|c|}
\hline INDEPENDENT VARIABLES & $(1)$ & $(2)$ & $(3)$ & $(4)$ \\
\hline $\mathrm{R} \& \mathrm{D}$ & $\begin{array}{c}1.408^{* * *} \\
{[3.22]}\end{array}$ & & & \\
\hline Log Patent & & $\begin{array}{c}14.328^{* * *} \\
{[2.99]}\end{array}$ & & \\
\hline Log Citation & & & $\begin{array}{c}6.044^{* * *} \\
{[3.10]}\end{array}$ & \\
\hline Innovation Index & & & & $\begin{array}{c}6.166^{* * *} \\
{[3.75]}\end{array}$ \\
\hline Firm Control Variables & Yes & Yes & Yes & Yes \\
\hline Observations & 3,554 & 3,554 & 3,554 & 3,554 \\
\hline Pseudo R-squared & $25.0 \%$ & $25.0 \%$ & $25.0 \%$ & $25.1 \%$ \\
\hline Industry \& Year Dummies & Yes & Yes & Yes & Yes \\
\hline
\end{tabular}

Panel E: Dependent Variable is Listed Options

\begin{tabular}{|c|c|c|c|c|}
\hline INDEPENDENT VARIABLES & $(1)$ & $(2)$ & $(3)$ & $(4)$ \\
\hline $\mathrm{R} \& \mathrm{D}$ & $\begin{array}{c}3.458^{* * *} \\
{[10.32]}\end{array}$ & & & \\
\hline Log Patent & & $\begin{array}{c}31.544^{* * *} \\
{[10.88]}\end{array}$ & & \\
\hline Log Citation & & & $\begin{array}{c}11.639^{* * *} \\
{[9.89]}\end{array}$ & \\
\hline Innovation Index & & & & $\begin{array}{c}14.207^{* * *} \\
{[13.09]}\end{array}$ \\
\hline Firm Control Variables & Yes & Yes & Yes & Yes \\
\hline Observations & 63,085 & 63,085 & 63,085 & 63,085 \\
\hline Pseudo R-squared & $41.7 \%$ & $41.2 \%$ & $41.2 \%$ & $41.1 \%$ \\
\hline Firm Random-effects & Yes & Yes & Yes & Yes \\
\hline Industry \& Year Dummies & Yes & Yes & Yes & Yes \\
\hline
\end{tabular}


Table 7: Actions of Innovative Firms and the Impact on Stock Liquidity. In this table, we show that the actions that innovative firms take do improve stock liquidity. We present estimates from instrumental variable regressions with firm random-effects where the dependent variable is Illiquidity measured in year $t+1$. The independent variables of interest include Guidance, Stock Splits, and SEO Dummy instrumented by Industry Median Guidance, Industry Mean Stock Splits, and Industry Mean SEO Dummy, respectively. In column (4), we instrument all three actions using the three instruments and, therefore, are unable to report all nine coefficients. We control for the firm's Innovation Index as well as the following firm characteristics.: Log Assets, Leverage, Cash, Tobin's Q, NYSE Dummy, ROA, Tangibility, Firm's Age and Return Volatility. Coefficients of the control variables are not reported for brevity. All the variables are defined in the Appendix. Year and industry dummies are also included.

\begin{tabular}{|c|c|c|c|c|}
\hline \multirow[b]{2}{*}{ INDEPENDENT VARIABLES } & \multicolumn{4}{|c|}{ Dependent Variable is Illiquidity } \\
\hline & $(1)$ & $(2)$ & $(3)$ & $(4)$ \\
\hline Guidance & $\begin{array}{c}-0.712^{* * *} \\
{[-5.24]}\end{array}$ & & & $\begin{array}{c}-0.960^{* * *} \\
{[-4.57]}\end{array}$ \\
\hline Split Dummy & & $\begin{array}{c}-5.409 * * * \\
{[-9.09]}\end{array}$ & & $\begin{array}{c}-4.541 \text { *** } \\
{[-6.31]}\end{array}$ \\
\hline SEO Dummy & & & $\begin{array}{c}-4.116^{* * *} \\
{[-8.63]}\end{array}$ & $\begin{array}{c}-1.762^{*} \\
{[-1.88]}\end{array}$ \\
\hline Innovation Index & $\begin{array}{c}-6.623^{* * *} \\
{[-15.06]}\end{array}$ & $\begin{array}{c}-4.714^{* * *} \\
{[-7.46]}\end{array}$ & $\begin{array}{c}-5.677 * * * \\
{[-11.54]}\end{array}$ & $\begin{array}{c}-5.488^{* * *} * \\
{[-8.36]}\end{array}$ \\
\hline Firm Control Variables & Yes & Yes & Yes & Yes \\
\hline $\begin{array}{l}\text { Observations } \\
\text { Firm Random-effects } \\
\text { Industry Dummies } \\
\text { Year Dummies }\end{array}$ & $\begin{array}{c}67,401 \\
\text { Yes } \\
\text { Yes } \\
\text { Yes }\end{array}$ & $\begin{array}{c}81,604 \\
\text { Yes } \\
\text { Yes } \\
\text { Yes }\end{array}$ & $\begin{array}{c}81,604 \\
\text { Yes } \\
\text { Yes } \\
\text { Yes }\end{array}$ & $\begin{array}{c}67,401 \\
\text { Yes } \\
\text { Yes } \\
\text { Yes } \\
\end{array}$ \\
\hline & & Dependen & Variable is: & \\
\hline FIRST-STAGE INSTRUMENTAL VARIABLES & Guidance & Stock Splits & SEO Dummy & \\
\hline Industry Guidance & $\begin{array}{c}0.254^{* * *} \\
{[21.55]}\end{array}$ & & & \\
\hline Industry Stock Splits & & $\begin{array}{c}0.355^{* * *} \\
{[11.31]}\end{array}$ & & \\
\hline Industry SEO Dummy & & & $\begin{array}{c}0.377^{* * *} * \\
{[13.05]}\end{array}$ & \\
\hline Firm-specific Control Variables & Yes & Yes & Yes & Yes \\
\hline R-squared & $77.0 \%$ & $64.1 \%$ & $71.7 \%$ & $67.7 \%$ \\
\hline
\end{tabular}


Table 8: Debt Financing by Innovative Firms. In this table, we show that innovative firms are more likely to issue public debt, have higher credit ratings, less likely to have any accounting-based quantitative loan covenants, and also have fewer such covenants in their loans. Panels A and C present Probit regressions where the dependent variable is Public Debt Dummy and Covenant Dummy, respectively. Panels B and D present Ordered Probit regressions where the dependent variable is Credit Rating and Number of Covenants, respectively. All the dependent variables are measured in year $t+1$ while the independent variables are measured in year $t$. The independent variables of interest include the four different proxies for innovation: RED, Log Patents, Log Citations, and Innovation Index. The following firm characteristics are also included in the regressions (but their coefficients are not reported for brevity): Log Assets, Leverage, Cash, Tobin's Q, NYSE Dummy, ROA, Tangibility, Firm's Age and Return Volatility. In the regressions for loan covenants, we also control for the following loan characteristics: Log Loan Amount, Log Loan Maturity and Syndicate Dummy. All the variables are defined in the Appendix. Year and industry dummies are also included.

Panel A: Dependent Variable is Public Debt Dummy

\begin{tabular}{|c|c|c|c|c|}
\hline INDEPENDENT VARIABLES & $(1)$ & $(2)$ & $(3)$ & $(4)$ \\
\hline $\mathrm{R} \& \mathrm{D}$ & $\begin{array}{l}0.077 \\
{[0.16]}\end{array}$ & & & \\
\hline Log Patent & & $\begin{array}{c}7.064^{* *} \\
{[2.54]}\end{array}$ & & \\
\hline Log Citation & & & $\begin{array}{c}5.730^{* * *} \\
{[4.68]}\end{array}$ & \\
\hline Innovation Index & & & & $\begin{array}{c}4.140 * * * \\
{[3.78]}\end{array}$ \\
\hline Firm Control Variables & Yes & Yes & Yes & Yes \\
\hline Observations & 81,846 & 81,846 & 81,846 & 81,846 \\
\hline Pseudo R-squared & $36.2 \%$ & $36.1 \%$ & $36.1 \%$ & $36.1 \%$ \\
\hline Firm Random-effects & Yes & Yes & Yes & Yes \\
\hline Industry Dummies & Yes & Yes & Yes & Yes \\
\hline Year Dummies & Yes & Yes & Yes & Yes \\
\hline
\end{tabular}

$* * * \mathrm{p}<0.01, * * \mathrm{p}<0.05, * \mathrm{p}<0.1$

Panel B: Dependent Variable is Credit Rating

\begin{tabular}{|c|c|c|c|c|}
\hline INDEPENDENT VARIABLES & (1) & $(2)$ & $(3)$ & $(4)$ \\
\hline $\mathrm{R} \& \mathrm{D}$ & $\begin{array}{l}-0.598 \\
{[-0.99]}\end{array}$ & & & \\
\hline Log Patent & & $\begin{array}{c}6.315^{* * *} \\
{[2.77]}\end{array}$ & & \\
\hline Log Citation & & & $\begin{array}{c}2.826^{* *} \\
{[2.52]}\end{array}$ & \\
\hline Innovation Index & & & & $\begin{array}{c}2.380^{* *} \\
{[2.53]}\end{array}$ \\
\hline Firm Control Variables & Yes & Yes & Yes & Yes \\
\hline Observations & 18,421 & 18,421 & 18,421 & 18,421 \\
\hline Pseudo R-squared & $33.7 \%$ & $33.7 \%$ & $33.7 \%$ & $33.7 \%$ \\
\hline Industry Dummies & Yes & Yes & Yes & Yes \\
\hline Year Dummies & Yes & Yes & Yes & Yes \\
\hline
\end{tabular}


Panel C: Dependent Variable is Covenant Dummy

\begin{tabular}{|c|c|c|c|c|}
\hline INDEPENDENT VARIABLES & (1) & $(2)$ & $(3)$ & $(4)$ \\
\hline $\mathrm{R} \& \mathrm{D}$ & $\begin{array}{l}0.280 \\
{[0.86]}\end{array}$ & & & \\
\hline Log Patent & & $\begin{array}{c}-12.166^{* * *} \\
{[-5.63]}\end{array}$ & & \\
\hline Log Citation & & & $\begin{array}{c}-4.829 * * * \\
{[-4.74]}\end{array}$ & \\
\hline Innovation Index & & & & $\begin{array}{c}-4.305 * * * \\
{[-5.09]}\end{array}$ \\
\hline Log Loan Amount & $\begin{array}{c}0.216^{* * *} \\
{[9.87]}\end{array}$ & $\begin{array}{c}0.220^{* * *} \\
{[9.95]}\end{array}$ & $\begin{array}{c}0.218^{* * *} \\
{[9.87]}\end{array}$ & $\begin{array}{c}0.218^{* * *} \\
{[9.93]}\end{array}$ \\
\hline Log Loan Maturity & $\begin{array}{c}0.158^{* * *} * \\
{[7.49]}\end{array}$ & $\begin{array}{c}0.154^{* * *} \\
{[7.25]}\end{array}$ & $\begin{array}{c}0.155^{* * *} \\
{[7.31]}\end{array}$ & $\begin{array}{c}0.154^{* * *} \\
{[7.27]}\end{array}$ \\
\hline Syndicate Dummy & $\begin{array}{c}0.107 * * * \\
{[2.61]}\end{array}$ & $\begin{array}{c}0.100^{* *} \\
{[2.45]}\end{array}$ & $\begin{array}{c}0.103^{* *} \\
{[2.51]}\end{array}$ & $\begin{array}{c}0.100 * * \\
{[2.45]}\end{array}$ \\
\hline Firm Control Variables & Yes & Yes & Yes & Yes \\
\hline Observations & 14,105 & 14,105 & 14,105 & 14,105 \\
\hline Pseudo R-squared & $24.4 \%$ & $24.7 \%$ & $24.6 \%$ & $24.6 \%$ \\
\hline Industry Dummies & Yes & Yes & Yes & Yes \\
\hline Year Dummies & Yes & Yes & Yes & Yes \\
\hline
\end{tabular}

Panel D: Dependent Variable is Number of Covenants

\begin{tabular}{|c|c|c|c|c|}
\hline INDEPENDENT VARIABLES & $(1)$ & $(2)$ & $(3)$ & $(4)$ \\
\hline $\mathrm{R} \& \mathrm{D}$ & $\begin{array}{c}-0.468^{*} \\
{[-1.65]}\end{array}$ & & & \\
\hline Log Patent & & $\begin{array}{c}-10.560 * * * \\
{[-6.10]}\end{array}$ & & \\
\hline Log Citation & & & $\begin{array}{c}-4.353^{* * *} \\
{[-5.27]}\end{array}$ & \\
\hline Innovation Index & & & & $\begin{array}{c}-4.052 * * * \\
{[-5.91]}\end{array}$ \\
\hline Log Loan Amount & $\begin{array}{c}0.104^{* * *} \\
{[5.64]}\end{array}$ & $\begin{array}{c}0.108^{* * *} \\
{[5.69]}\end{array}$ & $\begin{array}{c}0.107 * * * \\
{[5.63]}\end{array}$ & $\begin{array}{c}0.107^{* * *} \\
{[5.67]}\end{array}$ \\
\hline Log Loan Maturity & $\begin{array}{c}0.232^{* * *} \\
{[12.82]}\end{array}$ & $\begin{array}{c}0.230^{* * *} \\
{[12.60]}\end{array}$ & $\begin{array}{c}0.231^{* * *} \\
{[12.65]}\end{array}$ & $\begin{array}{c}0.230 * * * \\
{[12.60]}\end{array}$ \\
\hline Syndicate Dummy & $\begin{array}{c}0.208^{* * *} \\
{[6.03]}\end{array}$ & $\begin{array}{c}0.207 * * * \\
{[5.99]}\end{array}$ & $\begin{array}{c}0.209^{* * *} \\
{[6.04]}\end{array}$ & $\begin{array}{c}0.206^{* * *} \\
{[5.98]}\end{array}$ \\
\hline Firm Control Variables & Yes & Yes & Yes & Yes \\
\hline Observations & 14,105 & 14,105 & 14,105 & 14,105 \\
\hline Pseudo R-squared & $9.0 \%$ & $9.1 \%$ & $9.1 \%$ & $9.1 \%$ \\
\hline Industry Dummies & Yes & Yes & Yes & Yes \\
\hline Year Dummies & Yes & Yes & Yes & Yes \\
\hline
\end{tabular}


Table 9: Institutional Ownership, Blockholders, and Incentive Contracts in Innovative Firms. In this table, we show that the onus of monitoring the management of innovative firms rests on equity-holders. Panel A and $\mathrm{C}$ present regressions with firm random-effects, where the dependent variables are Institutional Ownership and Equity-Based Compensation respectively. Panel B presents Probit regressions with firm random-effects, where the dependent variable is Blockholder Dummy. All these dependent variables are measured in year $t+1$. The independent variables of interest, measured in year $t$, are the four different proxies for innovation: RED, Log Patents, Log Citations, and Innovation Index. The following firm characteristics, measured in year $t$, are also included in the regressions: Log Assets, Leverage, Cash, Tobin's Q, NYSE Dummy, ROA, Tangibility, Firm's Age, and Return Volatility. In Panel C, we also control for: CEO Age, CEO Tenure, CEO Ownership, and Free Cash Flows. All the variables are defined in the Appendix. Year and industry dummies are also included.

Panel A: Dependent Variable is Institutional Ownership

\begin{tabular}{|c|c|c|c|c|}
\hline INDEPENDENT VARIABLES & (1) & $(2)$ & $(3)$ & $(4)$ \\
\hline $\mathrm{R} \& \mathrm{D}$ & $\begin{array}{c}0.036^{* *} \\
{[2.03]}\end{array}$ & & & \\
\hline Log Patent & & $\begin{array}{c}1.789^{* * *} \\
{[9.67]}\end{array}$ & & \\
\hline Log Citation & & & $\begin{array}{c}0.327^{* * *} \\
{[5.11]}\end{array}$ & \\
\hline Innovation Index & & & & $\begin{array}{c}0.513^{* * *} \\
{[8.13}\end{array}$ \\
\hline Firm Control Variables & Yes & Yes & Yes & Yes \\
\hline Observations & 81,846 & 81,846 & 81,846 & 81,846 \\
\hline R-squared & $36.8 \%$ & $37.4 \%$ & $37.0 \%$ & $37.3 \%$ \\
\hline Firm Random-effects & Yes & Yes & Yes & Yes \\
\hline Industry Dummies & Yes & Yes & Yes & Yes \\
\hline Year Dummies & Yes & Yes & Yes & Yes \\
\hline
\end{tabular}

$t$-statistics using robust, firm-clustered standard errors are in brackets

$* * * \mathrm{p}<0.01, * * \mathrm{p}<0.05, * \mathrm{p}<0.1$

Panel B: Dependent Variable is Blockholder Dummy

\begin{tabular}{|c|c|c|c|c|}
\hline INDEPENDENT VARIABLES & $(1)$ & $(2)$ & $(3)$ & $(4)$ \\
\hline $\mathrm{R} \& \mathrm{D}$ & $\begin{array}{c}1.266^{* * *} \\
{[5.11]}\end{array}$ & & & \\
\hline Log Patent & & $\begin{array}{c}16.960^{* * *} \\
{[7.16]}\end{array}$ & & \\
\hline Log Citation & & & $\begin{array}{c}6.530^{* * *} \\
{[6.64]}\end{array}$ & \\
\hline Innovation Index & & & & $\begin{array}{c}7.219^{* * *} \\
{[8.21]}\end{array}$ \\
\hline Firm Control Variables & Yes & Yes & Yes & Yes \\
\hline Observations & 81,846 & 81,846 & 81,846 & 81,846 \\
\hline Pseudo R-squared & $28.0 \%$ & $27.9 \%$ & $27.9 \%$ & $27.8 \%$ \\
\hline Firm Random-effects & Yes & Yes & Yes & Yes \\
\hline Industry Dummies & Yes & Yes & Yes & Yes \\
\hline Year Dummies & Yes & Yes & Yes & Yes \\
\hline
\end{tabular}


Panel C: Dependent Variable is Equity-Based Compensation

\begin{tabular}{|c|c|c|c|c|}
\hline INDEPENDENT VARIABLES & $(1)$ & $(2)$ & $(3)$ & $(4)$ \\
\hline $\mathrm{R} \& \mathrm{D}$ & $\begin{array}{c}0.319^{* * *} \\
{[3.31]}\end{array}$ & & & \\
\hline Log Patent & & $\begin{array}{c}2.251^{* * *} \\
{[4.16]}\end{array}$ & & \\
\hline Log Citation & & & $\begin{array}{c}0.854^{* * *} \\
{[3.54]}\end{array}$ & \\
\hline Innovation Index & & & & $\begin{array}{c}0.925^{* * *} \\
{[4.56]}\end{array}$ \\
\hline CEO Age & $\begin{array}{c}-0.004 * * * \\
{[-5.87]}\end{array}$ & $\begin{array}{c}-0.004^{* * *} \\
{[-5.90]}\end{array}$ & $\begin{array}{c}-0.004 * * * \\
{[-5.86]}\end{array}$ & $\begin{array}{c}-0.004 * * * \\
{[-5.87]}\end{array}$ \\
\hline CEO Tenure & $\begin{array}{c}-0.000 * * * \\
{[-3.67]}\end{array}$ & $\begin{array}{c}-0.000 * * * \\
{[-3.76]}\end{array}$ & $\begin{array}{c}-0.000 * * * \\
{[-3.72]}\end{array}$ & $\begin{array}{c}-0.000 * * * \\
{[-3.75]}\end{array}$ \\
\hline CEO Ownership & $\begin{array}{c}-0.600^{* * *} \\
{[-8.06]}\end{array}$ & $\begin{array}{c}-0.604^{* * *} \\
{[-8.16]}\end{array}$ & $\begin{array}{c}-0.607 * * * \\
{[-8.18]}\end{array}$ & $\begin{array}{c}-0.600^{* * *} \\
{[-8.08]}\end{array}$ \\
\hline Free Cash Flow & $\begin{array}{c}-0.052^{* *} \\
{[-2.02]}\end{array}$ & $\begin{array}{c}-0.060^{* *} \\
{[-2.33]}\end{array}$ & $\begin{array}{c}-0.060^{* *} \\
{[-2.33]}\end{array}$ & $\begin{array}{c}-0.059^{* *} \\
{[-2.28]}\end{array}$ \\
\hline Firm Control Variables & Yes & Yes & Yes & Yes \\
\hline Observations & 7,932 & 7,932 & 7,932 & 7,932 \\
\hline R-squared & $19.1 \%$ & $19.2 \%$ & $19.1 \%$ & $19.3 \%$ \\
\hline Firm Random-effects & Yes & Yes & Yes & Yes \\
\hline Industry Dummies & Yes & Yes & Yes & Yes \\
\hline Year Dummies & Yes & Yes & Yes & Yes \\
\hline
\end{tabular}

$t$-statistics using robust, firm-clustered standard errors are in brackets *** $\mathrm{p}<0.01, * * \mathrm{p}<0.05,{ }^{*} \mathrm{p}<0.1$ 


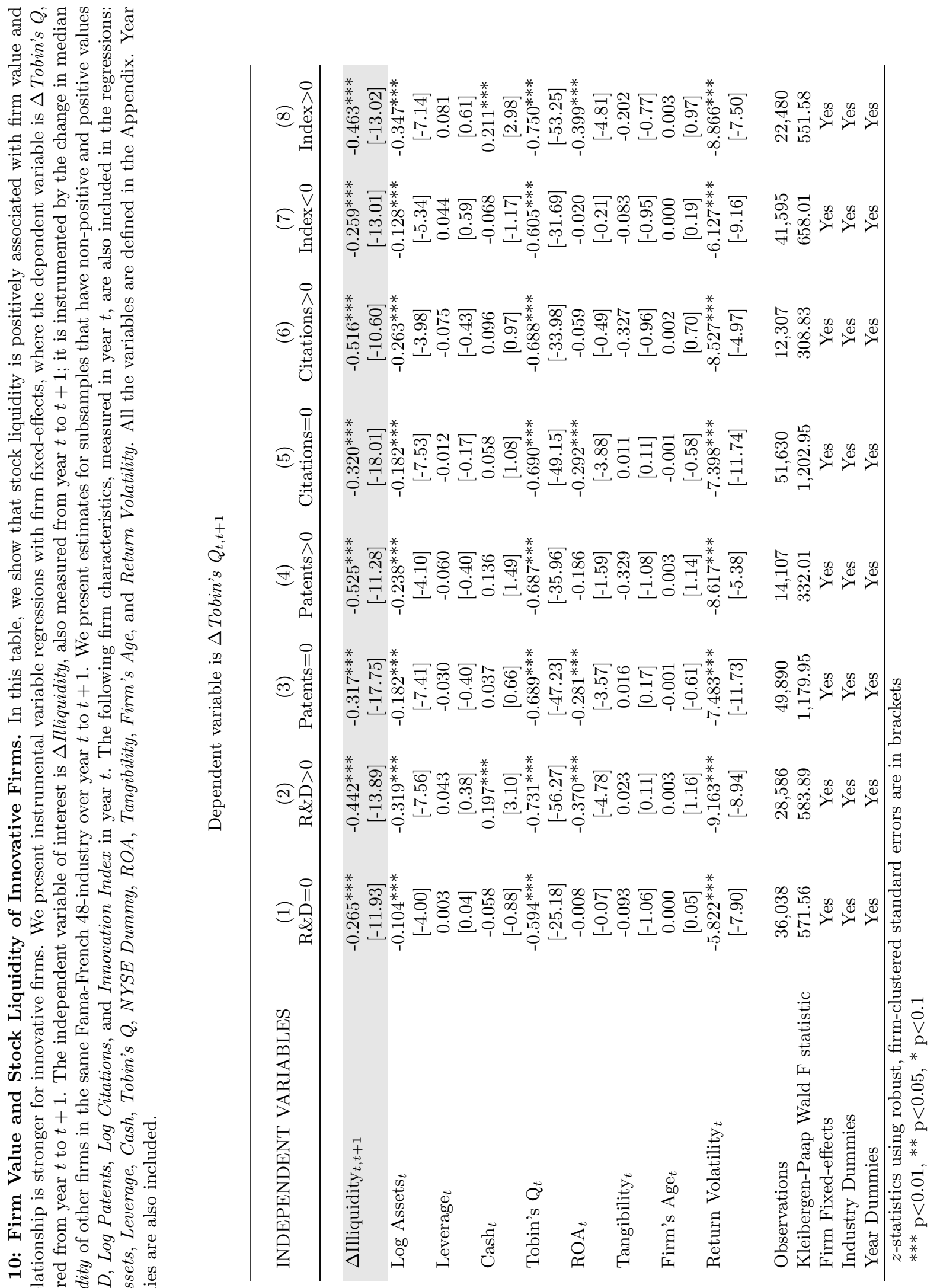




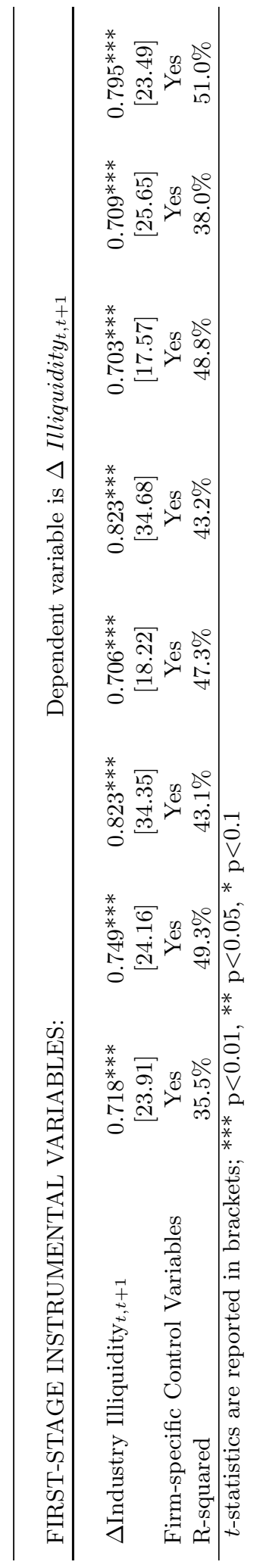




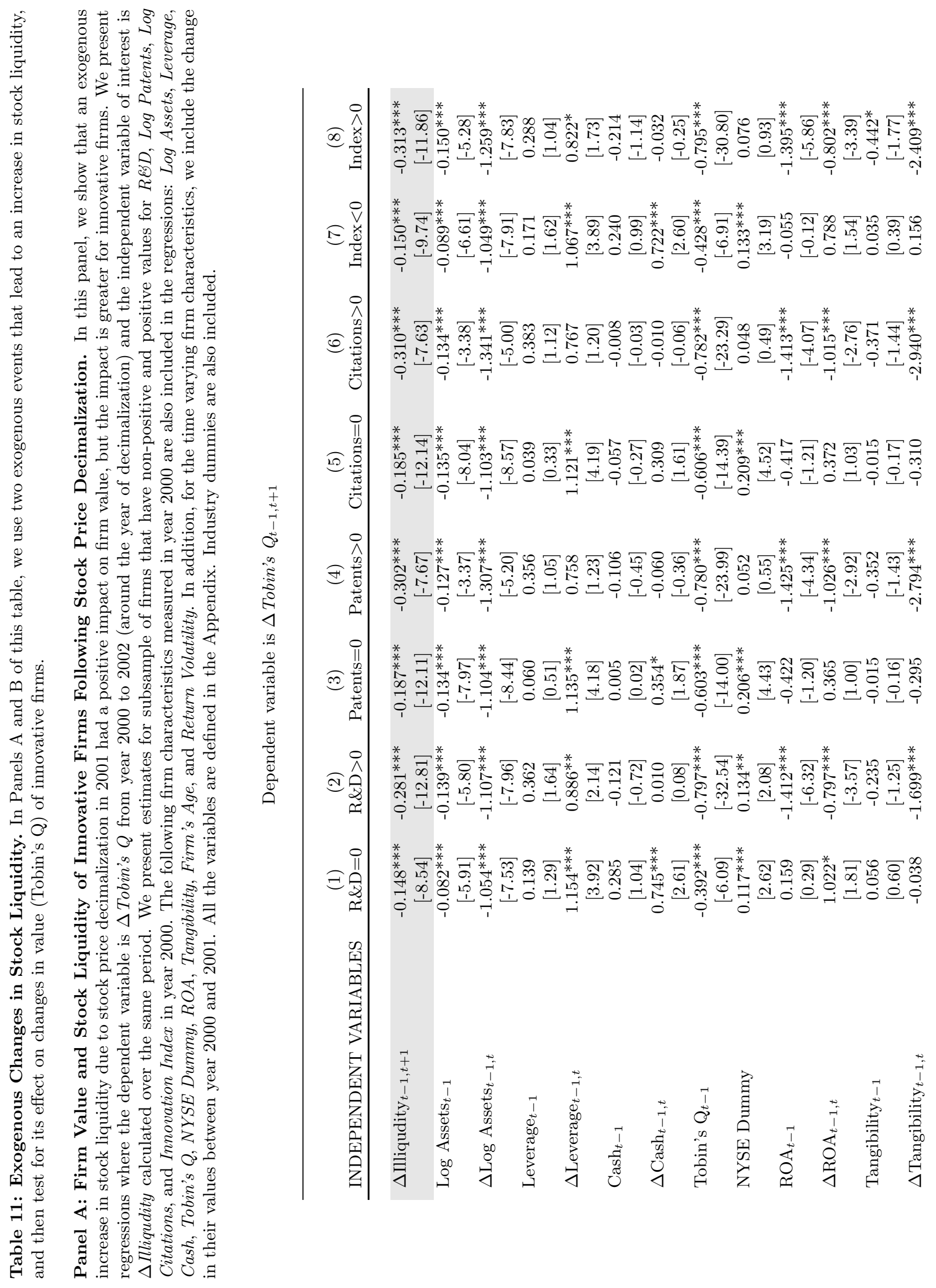




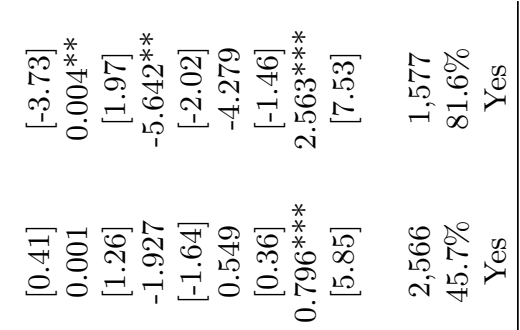

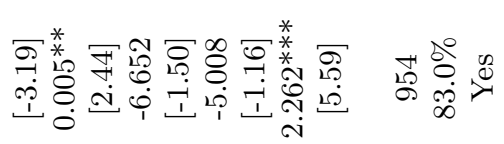

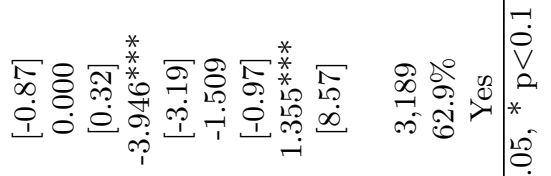

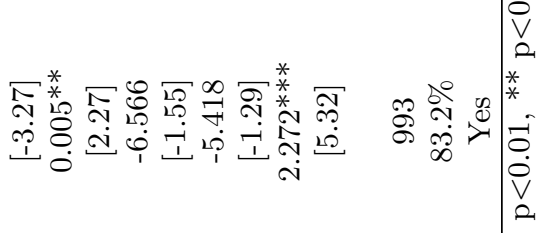

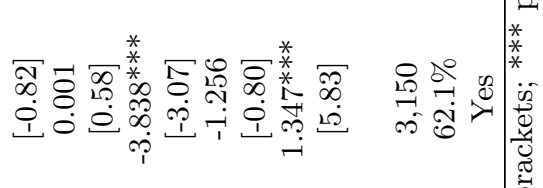

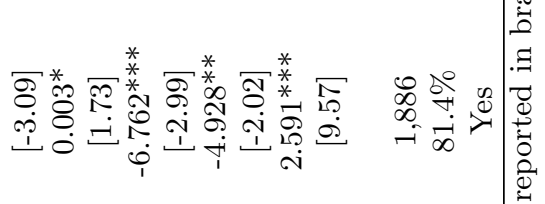

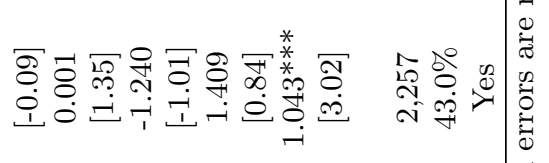

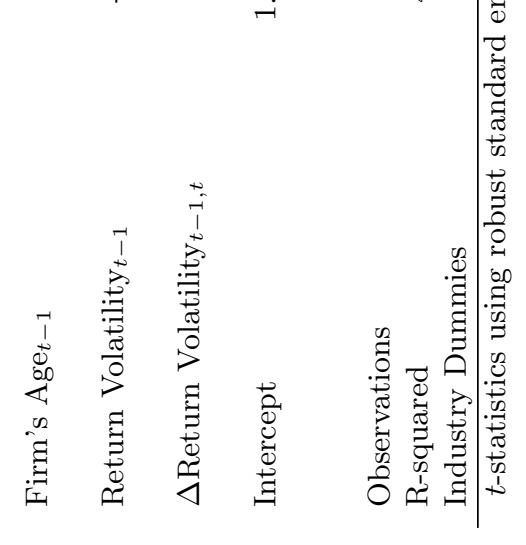

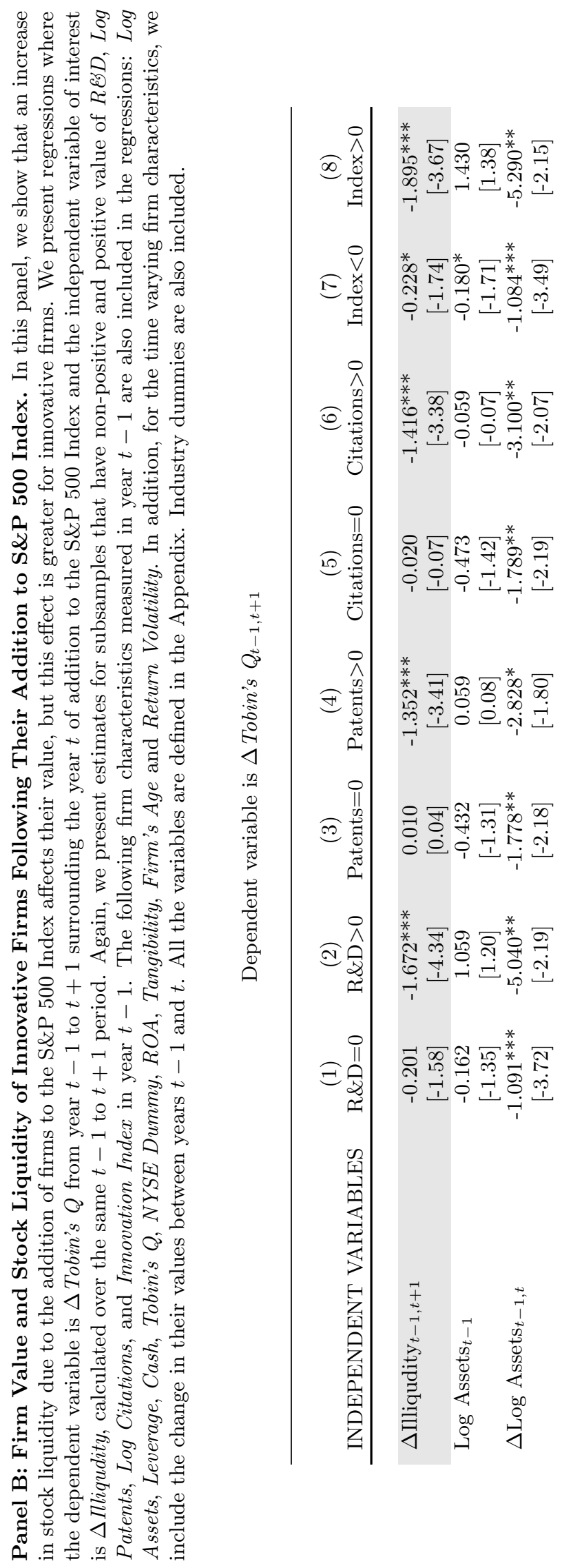




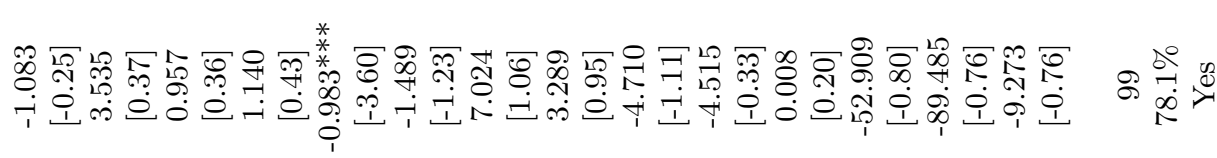

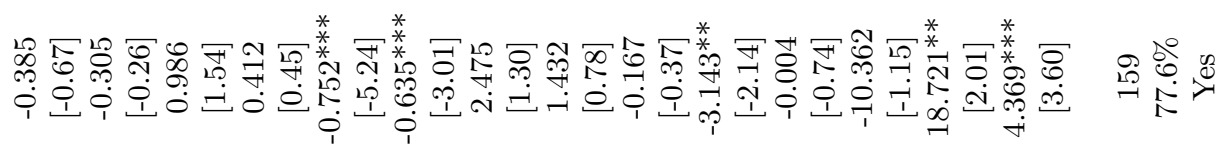

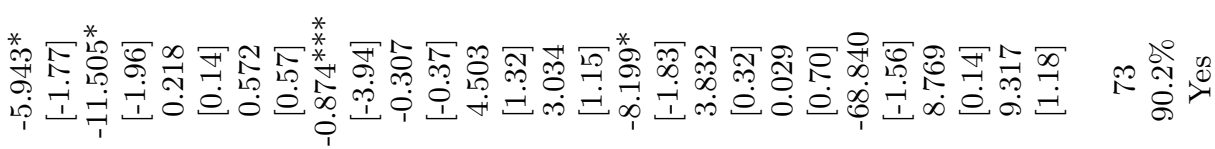

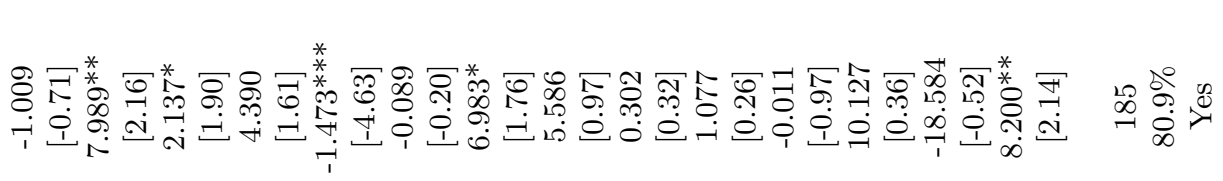

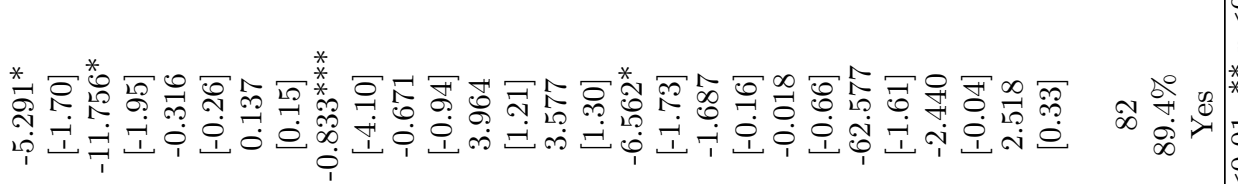

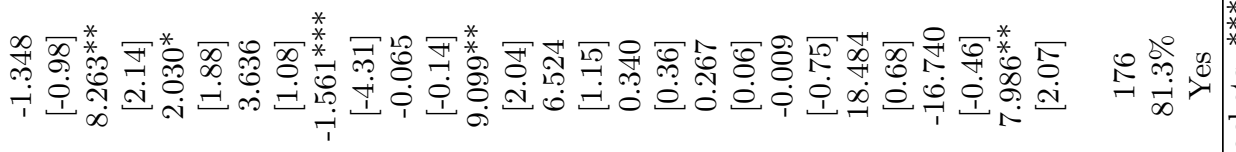

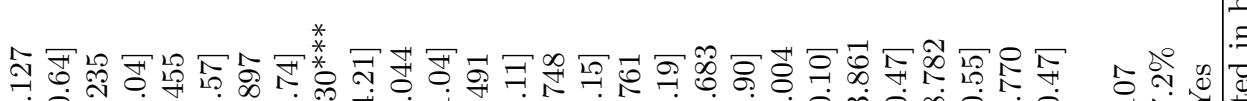

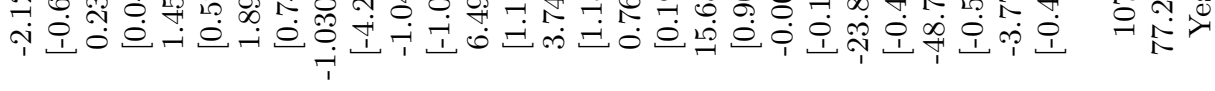

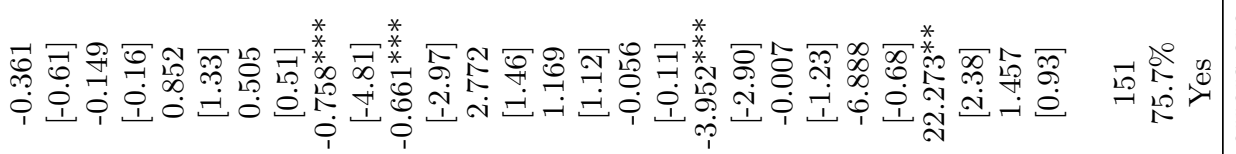

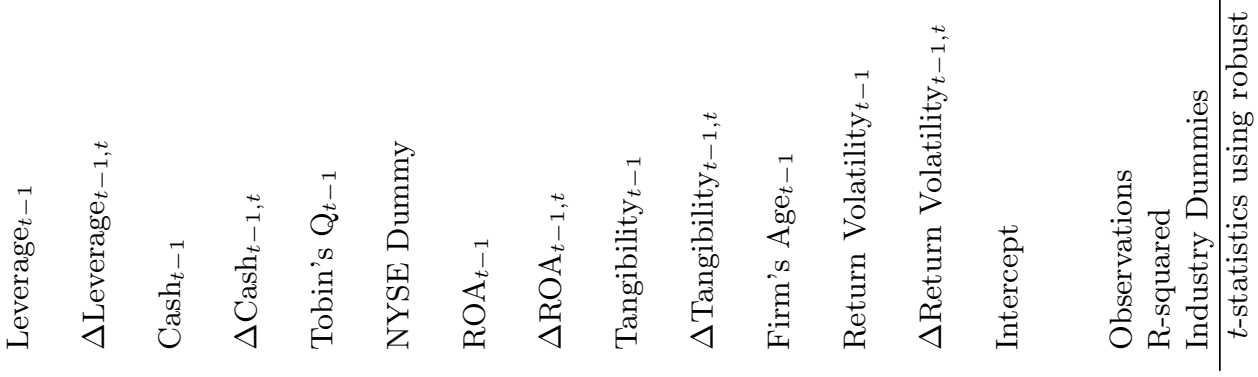




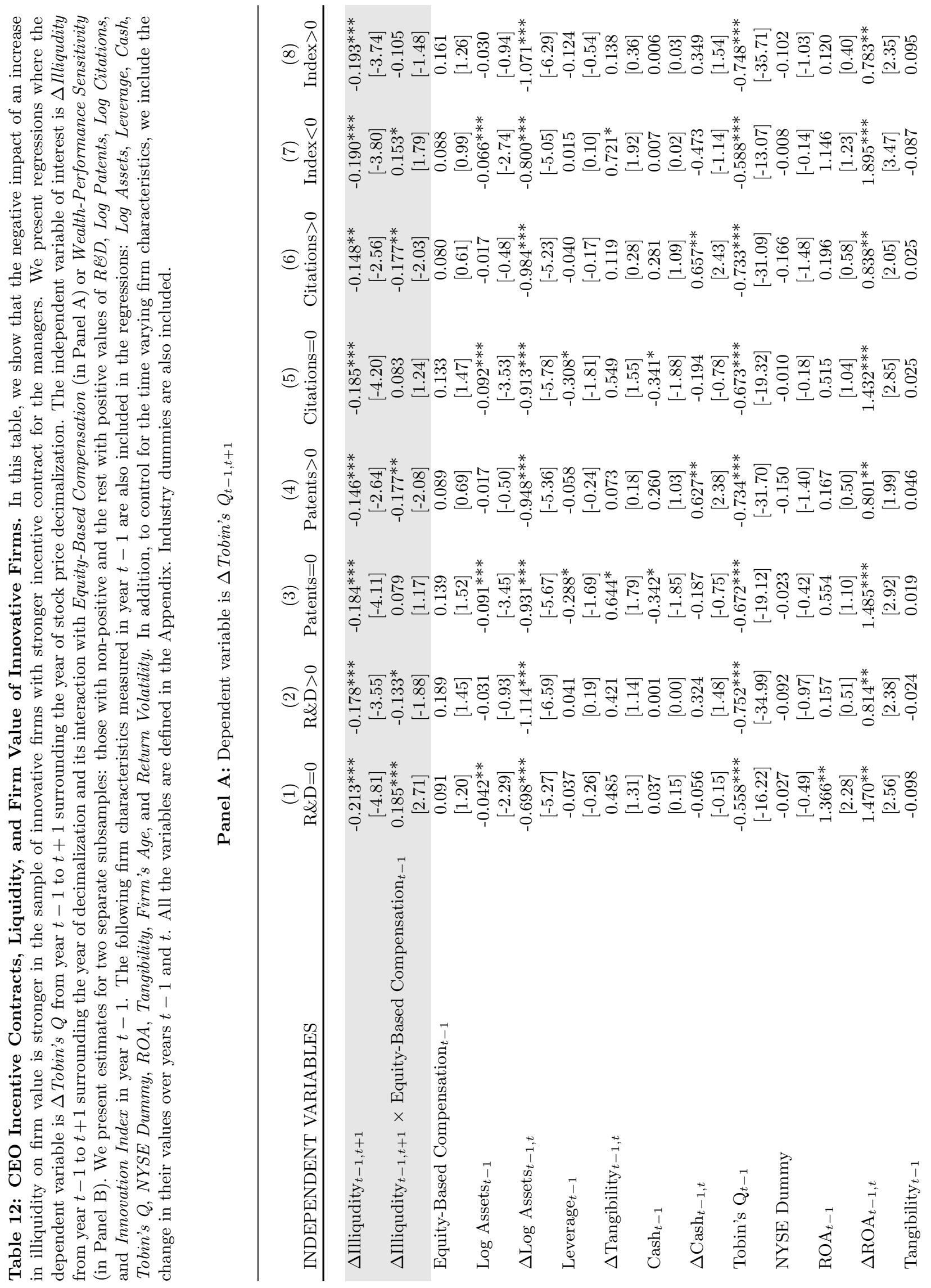




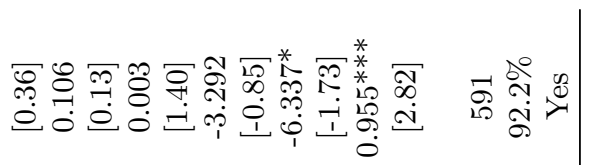

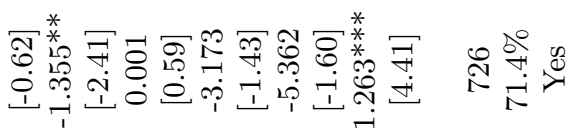

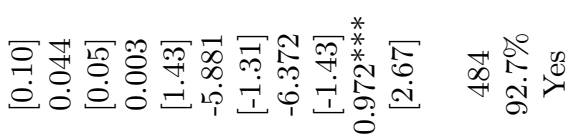

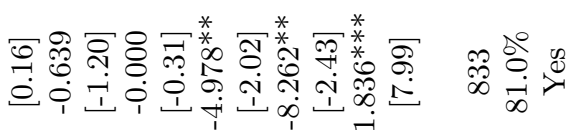

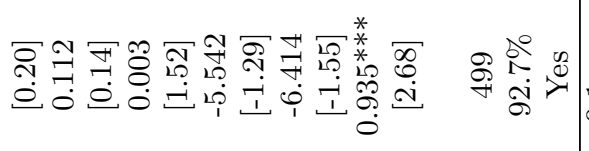

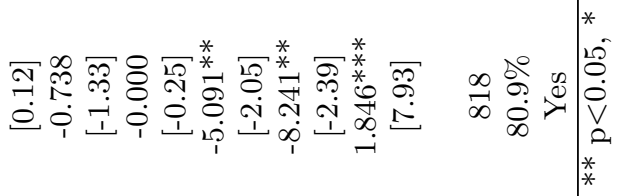

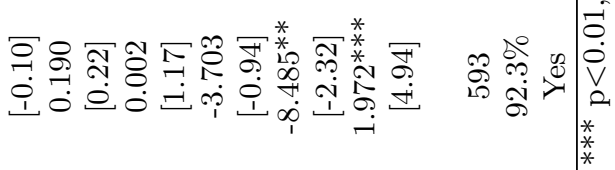

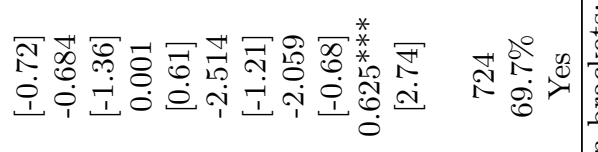

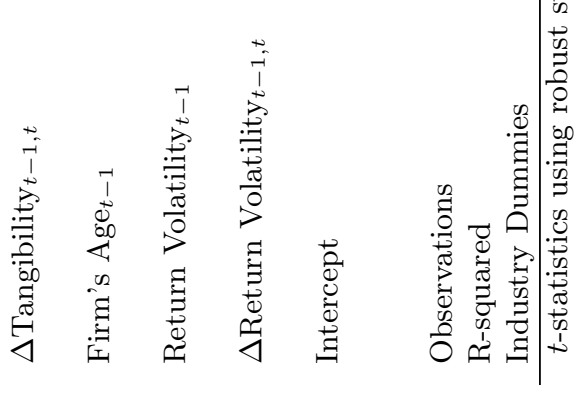

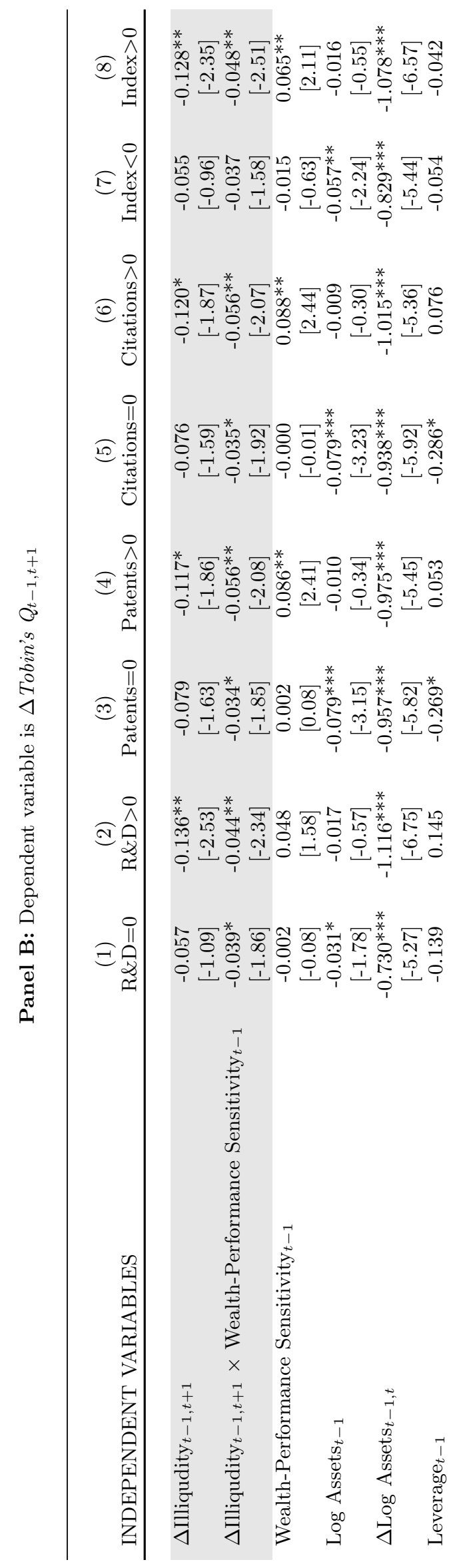




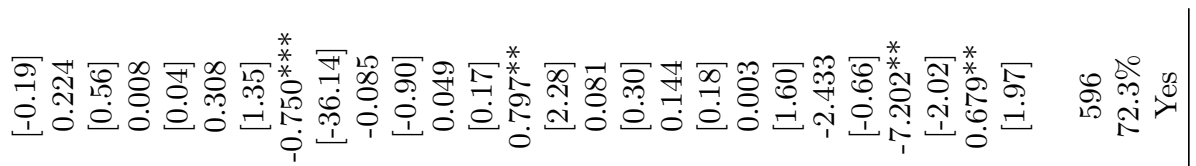

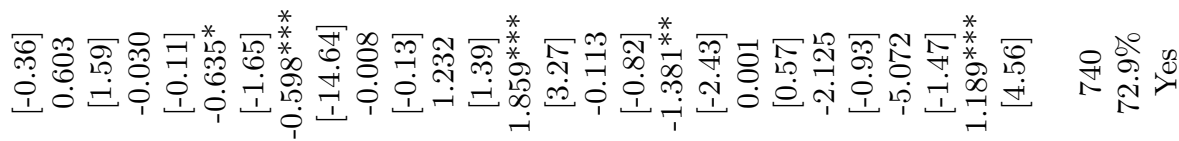

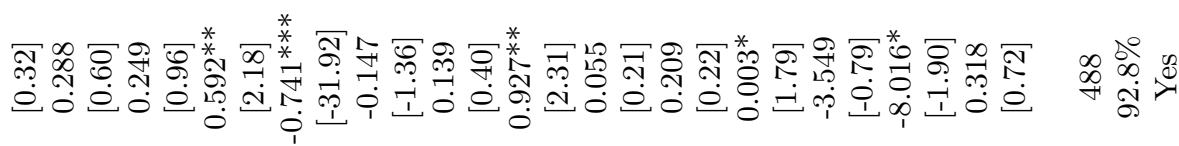

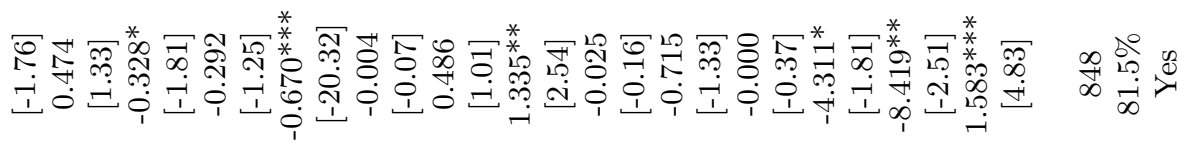

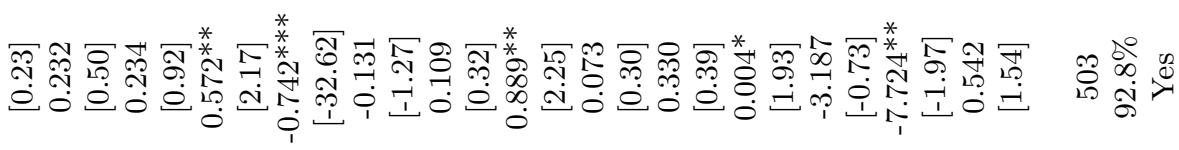

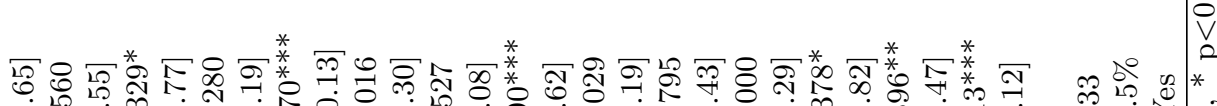

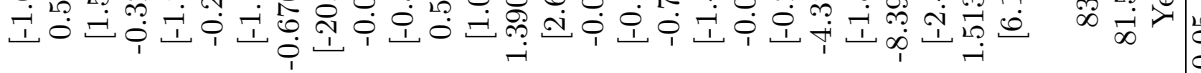

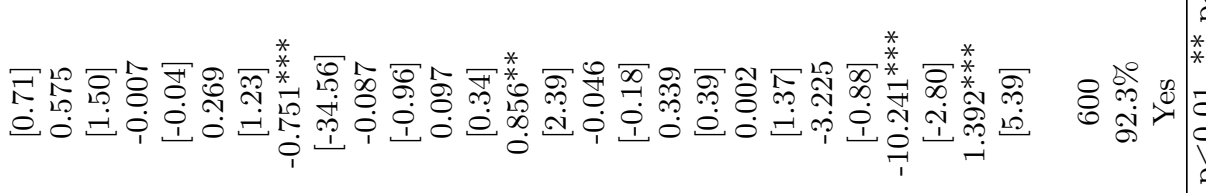

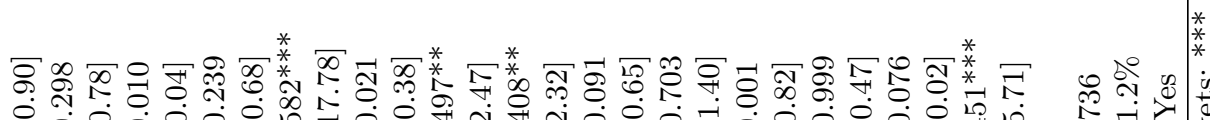

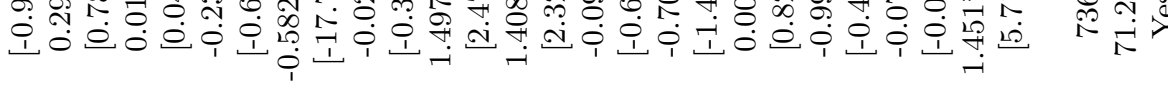

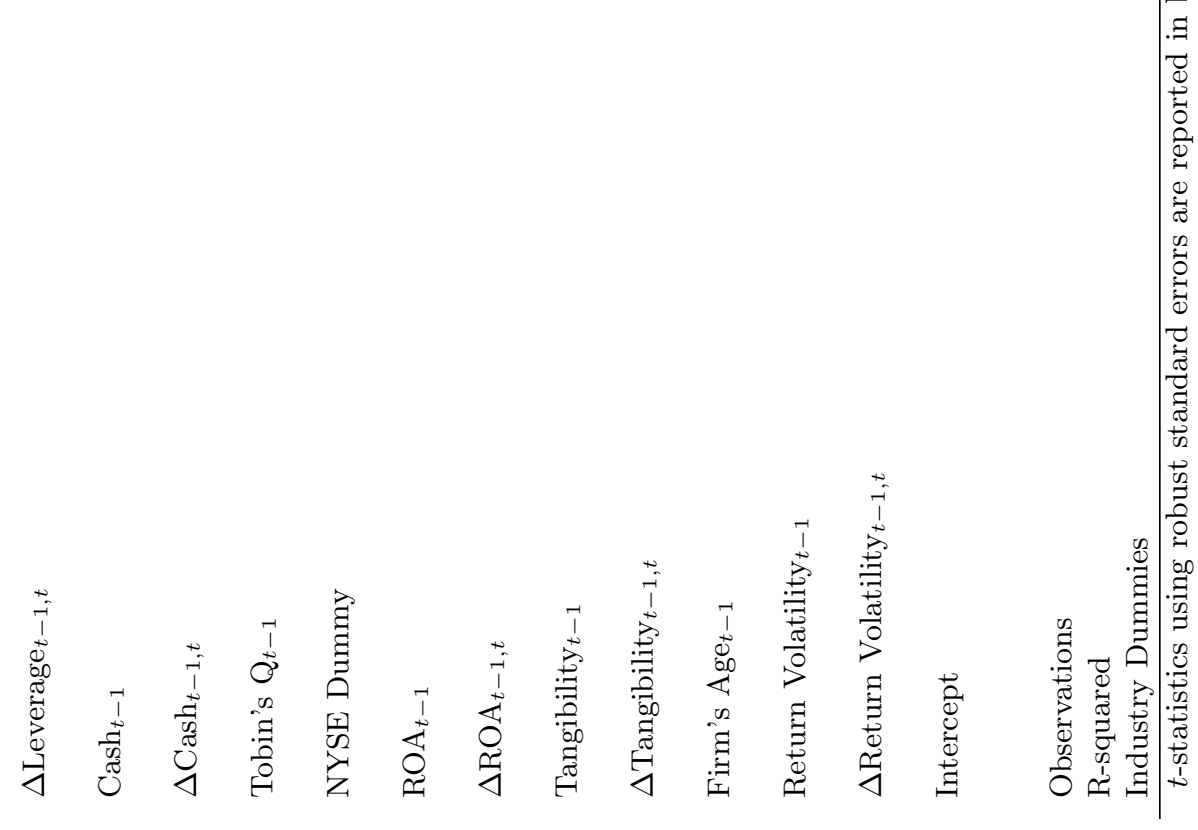




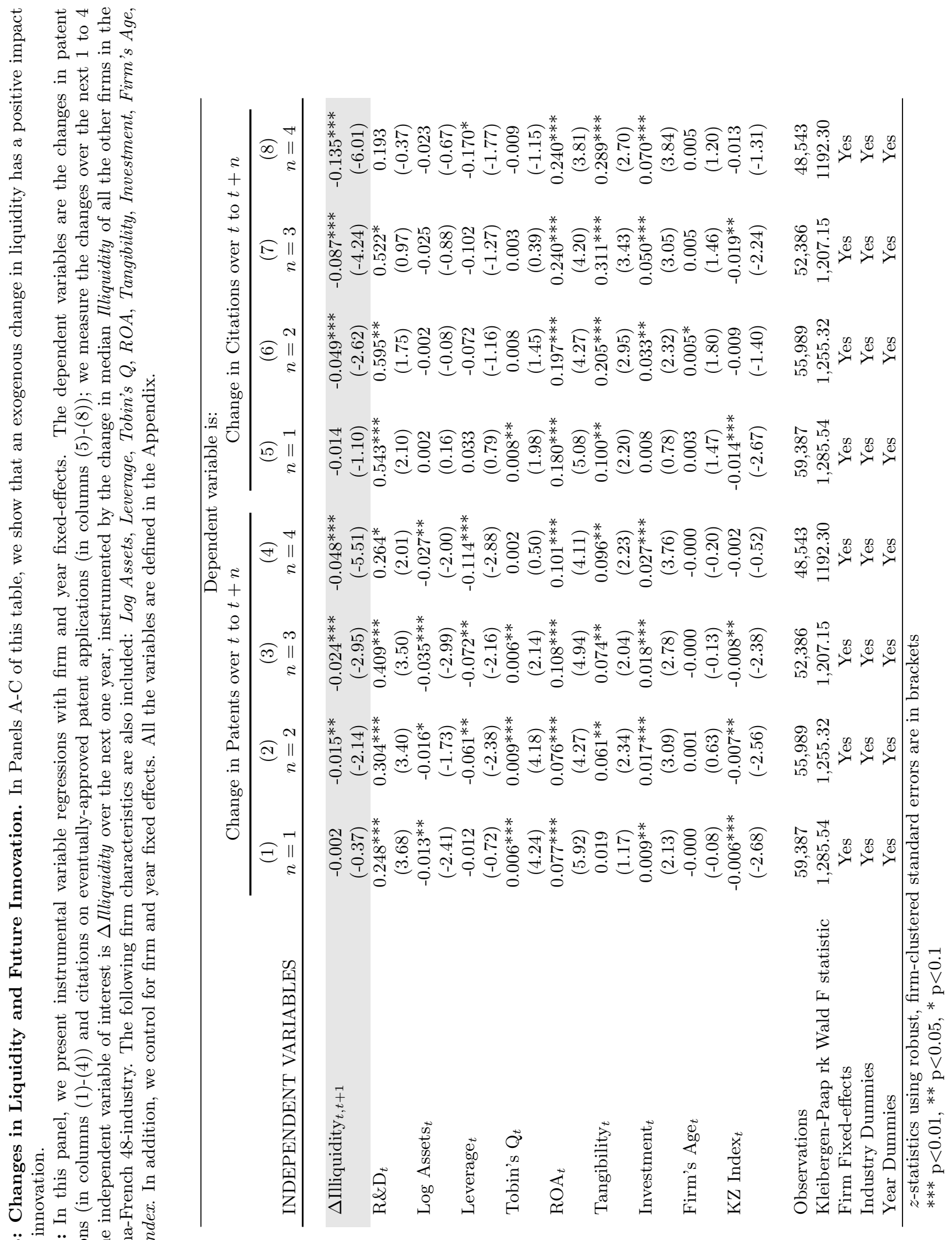



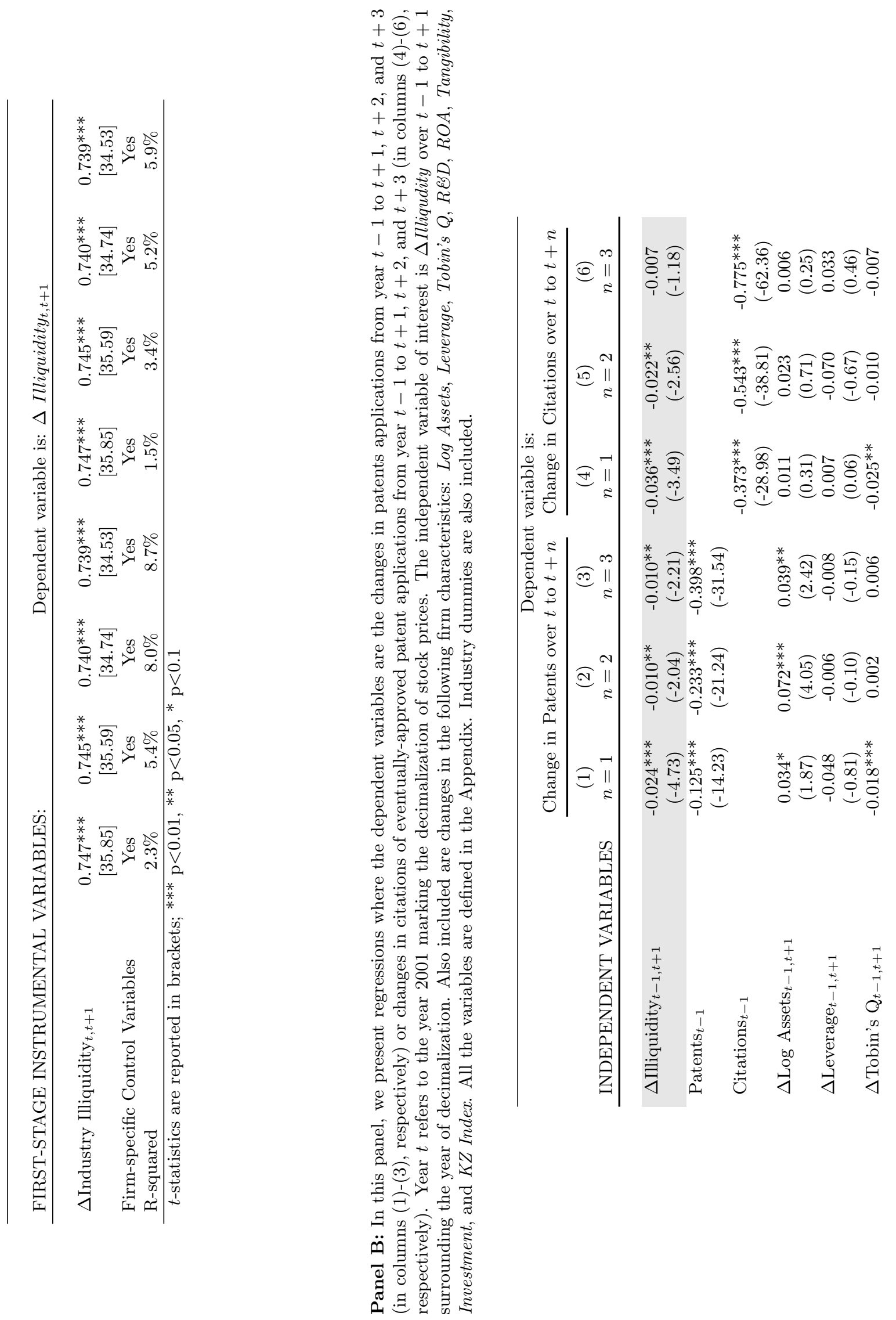

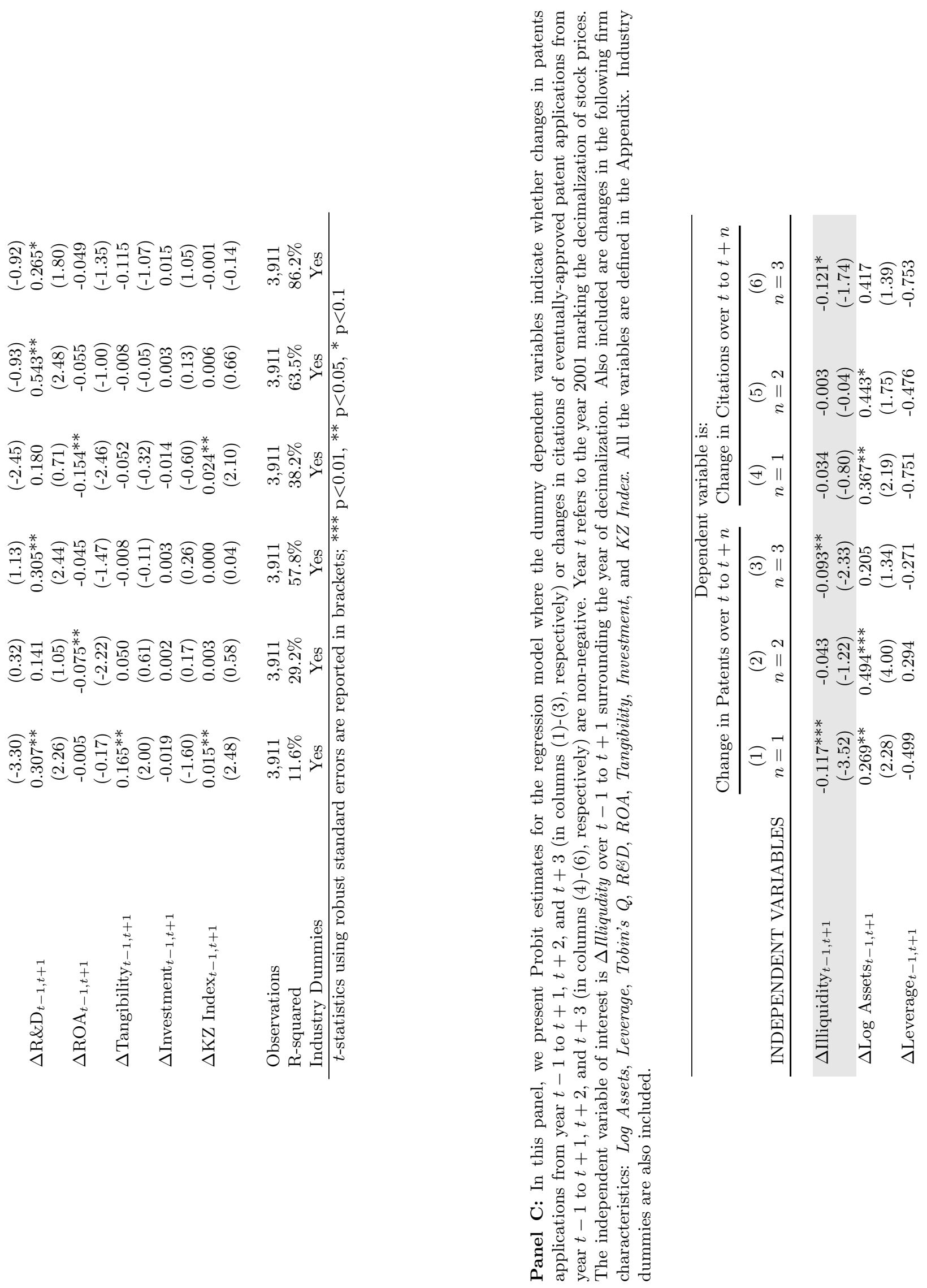


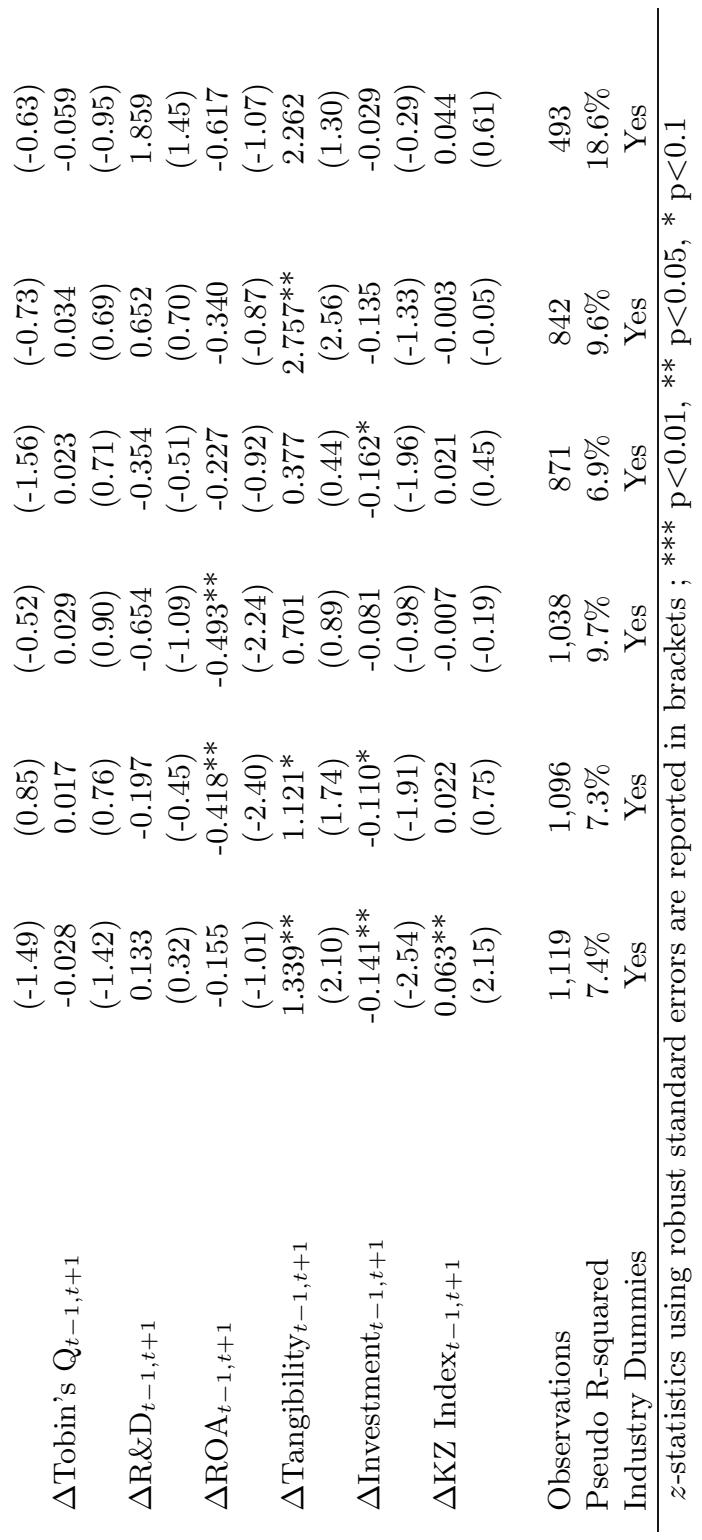

